\title{
Fossil evidence for low gas exchange capacities for Early Cretaceous angiosperm leaves
}

\author{
Author(s): Taylor S. Feild, Garland R. Upchurch Jr., David S. Chatelet, Timothy \\ J. Brodribb, Kunsiri C. Grubbs, Marie-Stéphanie Samain, and Stefan Wanke \\ Source: Paleobiology, 37(2):195-213. 2011. \\ Published By: The Paleontological Society
}

DOI: $10.1666 / 10015.1$

URL: http://www.bioone.org/doi/full/10.1666/10015.1

BioOne (www.bioone.org) is an electronic aggregator of bioscience research content, and the online home to over 160 journals and books published by not-for-profit societies, associations, museums, institutions, and presses.

Your use of this PDF, the BioOne Web site, and all posted and associated content indicates your acceptance of BioOne's Terms of Use, available at www.bioone.org/page/terms_of_use.

Usage of BioOne content is strictly limited to personal, educational, and non-commercial use. Commercial inquiries or rights and permissions requests should be directed to the individual publisher as copyright holder. 


\title{
Fossil evidence for low gas exchange capacities for Early Cretaceous angiosperm leaves
}

\author{
Taylor S. Feild, Garland R. Upchurch Jr., David S. Chatelet, Timothy J. Brodribb, \\ Kunsiri C. Grubbs, Marie-Stéphanie Samain, and Stefan Wanke
}

\begin{abstract}
The photosynthetic gas exchange capacities of early angiosperms remain enigmatic. Nevertheless, many hypotheses about the causes of early angiosperm success and how angiosperms influenced Mesozoic ecosystem function hinge on understanding the maximum capacity for early angiosperm metabolism. We applied structure-functional analyses of leaf veins and stomatal pore geometry to determine the hydraulic and diffusive gas exchange capacities of Early Cretaceous fossil leaves. All of the late Aptian-early Albian angiosperms measured possessed low vein density and low maximal stomatal pore area, indicating low leaf gas exchange capacities in comparison to modern ecologically dominant angiosperms. Gas exchange capacities for Early Cretaceous angiosperms were equivalent or lower than ferns and gymnosperms. Fossil leaf taxa from Aptian to Paleocene sediments previously identified as putative stem-lineages to Austrobaileyales and Chloranthales had the same gas exchange capacities and possibly leaf water relations of their living relatives. Our results provide fossil evidence for the hypothesis that high leaf gas exchange capacity is a derived feature of later angiosperm evolution. In addition, the leaf gas exchange functions of austrobaileyoid and chloranthoid fossils support the hypothesis that comparative research on the biology of living basal angiosperm lineages reveals genuine signals of Early Cretaceous angiosperm ecophysiology.
\end{abstract}

Taylor S. Feild.* School of Biological Sciences, Monash University, Clayton Campus, Australia. E-mail: hedyosmum@gmail.com

David S. Chatelet. Department of Ecology and Evolutionary Biology, University of Tennessee, Knoxville, Tennessee 37996

Timothy J. Brodribb. Department of Plant Science, University of Tasmania, Hobart, Tasmania, Australia

Garland R. Upchurch. Department of Biology, Texas State University, San Marcos, Texas

Kunsiri C. Grubbs. Department of Biology, Winthrop University, Rock Hill, South Carolina

Marie-Stéphanie Samain. Ghent University, Department of Biology, Research Group Spermatophytes, B-9000 Ghent, Belgium

Stefan Wanke. Technische Universität Dresden, Institut fur Botanik, 01062 Dresden, Germany

*Corresponding author

Accepted: 29 September 2010

\section{Introduction}

Evolutionary transitions in the ways organisms process energy and resources represent pivotal turning points in the history of life (Vermeij 1999). In particular, evolutionary changes in plant metabolic function cascade across a network of planet-wide biogeochemical and hydrological processes. Of the major transitions in plant gas exchange function, diverse lines of evidence point to the emergence of highly photosynthetically active angiosperm leaves as a transformative shift underpinning the assembly of modern ecosystem processes (Boyce et al. 2009; Brodribb and Feild 2010). For example, maximal leaf gas exchange capacities that define today's ecologically dominant angiosperms far outstrip those of all known non-angiosperms
(Körner 1995; Lusk et al. 2003; Brodribb et al. 2007; Boyce et al. 2009; Brodribb and Feild 2010). The evolution of high leaf gas exchange capacity may have stabilized or increased gross primary productivity of the vegetation under conditions of falling $\mathrm{CO}_{2}$ during the Cretaceous and/or later Cenozoic (Volk 1989; Robinson 1994; McElwain et al. 2005; Bond and Scott 2010). In addition, the functional prerequisites for constructing leaves capable of high rates of photosynthesis and functional by-products of such leaves as they transpire and eventually decompose may have elicited enhanced positive feedbacks on vegetationhydrological cycle interactions, fire frequency, nutrient cycles, and weathering and biomineralization processes that changed climates and/or formed new selective inter- 
faces for diverse organisms during the Cretaceous (Volk 1989; Robinson 1994; Martin 1995; Boyce et al. 2009; Taylor et al. 2009; Bond and Scott 2010; Brodribb and Feild 2010). However, an unresolved issue is when high leaf gas exchange of angiosperm leaves first evolved, and how this functional transition influenced early angiosperm evolution (Wing and Boucher 1998; Feild et al. 2009; Brodribb and Feild 2010).

An influential hypothesis is that the earliest angiosperms functioned with high photosynthetic gas exchange capacities (Stebbins 1974; Doyle and Hickey 1976; Hickey and Doyle 1977; Retallack and Dilcher 1981, 1986; Taylor and Hickey 1996). Paleoecological interpretations of the ecomorphology and depositional environments of Early Cretaceous fossil angiosperm leaves suggested that high photosynthetic capacity and high rates of weedy growth favored initial angiosperm success in sun-exposed point-bar zones along fast moving rivers (Stebbins 1974; Doyle and Hickey 1976; Hickey and Doyle 1977; Retallack and Dilcher 1981, 1986; Taylor and Hickey 1996). Thus, the evolution of high leaf gas exchange capacity by angiosperms did not spark the global ecological sweep of the angiosperms. Such is the case because the earliest angiosperms, while capable of high productivity, remained rare and ecologically confined to early successional zones for nearly $20 \mathrm{Myr}$ after their first fossil appearance (Hickey and Doyle 1977; Wing and Boucher 1998; Heimhofer et al. 2005). Later evolution of other functions in the reproductive system and/or mutualisms with animals gave considerable lift to angiosperm ecological success and allowed the export of high leaf gas exchange capacity to diverse environments.

By contrast, comparative ecophysiological evidence from extant early diverging angiosperm lineages motivated a hypothesis that the first angiosperms functioned with low metabolic capacity (Feild et al. 2004, 2009). Low leaf gas exchange capacity was associated with the early diversification of angiosperms in low-evaporative-demand, shady habitats underneath forest canopies formed by gymnosperms and ferns. Later, angiosperms evolved greater capacities for photo- synthesis and transpiration, as they dominated forest canopies and open disturbed zones. Under this hypothesis, the rise in ecological abundance of angiosperms evolved synchronously with their ability to expand into a range of high photosynthetic capacities previously unexplored by other vascular plants (Brodribb and Feild 2010). However, there is no known fossil evidence supporting the hypothesis that the earliest angiosperms functioned with low leaf gas exchange potential. Indeed, any literal reading of early angiosperm leaf gas exchange evolution based on extant basal angiosperm taxa is fraught with uncertainty. Uncertainty exists because these lineages experienced considerable range contraction over the last $100 \mathrm{Myr}$, they may have become ecologically modified by later angiosperm evolution or shifts in global environment, and they may fail to sample extinct early angiosperm functional diversity (Feild et al. 2009; Royer et al. 2010).

Recent discoveries on how leaf vein and stomatal pore anatomy determine leaf gas exchange capacity offer new potential for testing hypotheses on early angiosperm leaf gas exchange function in the fossil record (Brodribb et al. 2007; Boyce et al. 2009; Brodribb and Feild 2010; McKown et al. 2010). These new approaches are potentially informative because previous inferences were based on traits, including leaf size, leaf shape, major vein architecture patterns, and estimated leaf mass per area of fossil leaves, which cannot accurately specify where a species falls along a spectrum of low to high leaf gas exchange capacity nor specify the hydraulic costs of leaf photosynthesis (Doyle and Hickey 1976; Hickey and Doyle 1977; Retallack and Dilcher 1981, 1986; Taylor and Hickey 1996; Ackerly and Donoghue 1998; Wing and Boucher 1998; Royer et al. 2010).

The first goal of our investigation was to explore how venation and stomatal pore structure are linked to leaf gas exchange capacity and to use these mechanistic linkages to test previous hypotheses on how early angiosperm fossil leaves functioned. The focus is on fossil Zone I leaves from the Potomac Group of North America because these fossils represent one of the oldest 
known records of early angiosperm leaves, and these fossils formed the conceptual cornerstone of the ancestral weed hypothesis (Doyle and Hickey 1976; Hickey and Doyle 1977; Taylor and Hickey 1996). The second goal was to determine whether gas exchange capacities of fossil leaves related to extant terrestrial basal angiosperm lineages, specifically Austrobaileyales and Chloranthales, fell outside the range of extant relatives. The purpose of these comparisons was to evaluate the hypothesis that similar leaf gas exchange capacities have been conserved in extant basal angiosperm leaves since the Cretaceous. To do so, we determined the relations among vein and stomatal pore anatomy with leaf gas exchange capacity across a broad sample of extant basal angiosperm leaves and used them to interpret fossil leaf function.

\section{Methods}

Abbreviations. $-D_{\mathrm{v}}$, vein density (mm $\left.\mathrm{mm}^{-2}\right) ; g_{\mathrm{c}}^{\text {STOMA }}$, maximum stomatal conductance to water vapor calculated from stomatal pore geometry $\left(\mathrm{mmol} \mathrm{H}_{2} \mathrm{O} \mathrm{m}^{-2} \mathrm{~s}^{-1}\right) ; g_{\mathrm{c}}{ }^{\text {VEIN }}$, maximal stomatal conductance to water vapor calculated from vein density $\left(\mathrm{mmol} \mathrm{H}_{2} \mathrm{O}\right.$ $\left.\mathrm{m}^{-2} \mathrm{~s}^{-1}\right) ; g_{\mathrm{m}}$, measured maximum stomatal conductance to water vapor $\left(\mathrm{mmol} \mathrm{H}_{2} \mathrm{O}\right.$ $\left.\mathrm{m}^{-2} \mathrm{~s}^{-1}\right) ; P_{\mathrm{C}}$, measured maximum photosynthetic capacity on leaf area basis $\left(\mu \mathrm{mol} \mathrm{CO}_{2}\right.$ $\left.\mathrm{m}^{-2} \mathrm{~s}^{-1}\right) ; \Psi$, water potential $(\mathrm{MPa}) ; \Psi_{\text {leaf }}$, leaf water potential (MPa); $\Psi_{\text {soil }}$, soil water potential $(\mathrm{MPa}) ; S_{\mathrm{D}}$, stomatal density (number $\left.\mathrm{mm}^{-2}\right) ; S_{\mathrm{L}}$, stomatal guard cell length $(\mu \mathrm{m})$; $S_{\mathrm{W}}$ stomatal guard cell width $(\mu \mathrm{m})$; Pore $_{\mathrm{L}}$, stomatal pore length $(\mu \mathrm{m})$; Pore $_{\mathrm{D}}$, stomatal pore depth $(\mu \mathrm{m})$; SPA, stomatal pore area at maximal aperture $\left(\mathrm{m}^{2}\right)$; VPD, vapor pressure deficit (kPa).

Extant Species and Fossil Leaf Collections.The comparative investigations of leaf structure-function focused on 87 species of extant basal angiosperms, including Amborella, Nymphaeales, Austrobaileyales, and Chloranthales (Appendix I in the supplementary material online at http://dx.doi.org/10.1666/10015. s1). Most species studied were in natural populations in Australia, Costa Rica, China, Dominican Republic, French Polynesia, Fiji, Jamaica, New Caledonia, New Zealand, Peru,
Papua New Guinea, Thailand, United States, and Vietnam. Ten individuals per species were sampled. In addition, we studied 18 species, represented by three to ten individuals, in an outdoor garden collection in Knoxville, Tennessee. Plants were watered using a timed drip irrigation system, and all plants received fertilization every two to three weeks to ensure healthy leaves for physiological measurements. The species sampled encompassed the modern diversity of life form, life zone, and regeneration ecology found in extant terrestrial basal angiosperms (Appendix I, online) (Feild et al. 2004, 2009). Diverse lines of phylogenetic and paleobotanical data support these lineages as having diverged near the base of extant angiosperm phylogeny (Jansen et al. 2007; Moore et al. 2007; Saarela et al. 2007; Feild et al. 2009; Endress and Doyle 2009).

To examine intraspecific variation of leaf structure in relation to light, we sampled sun and shade leaves of each species when possible. Sun and shade environments were designated by field observations (Keeling and Phillips 2007). Sun leaves were taken as those that fully expanded under greater than $70 \%$ exposure to open sky. Shade leaves were taken as those that fully expanded in the forest understory, defined as less than 5\% exposure to open sky. For shade-demanding and short-lived pioneer species, only shade and sun leaves were available for sampling, respectively.

Details on the localities, ages, and proposed systematics of the sampled fossils are summarized in Appendix II (online). The fossils represented seven localities spanning approximately 60 Myr (early Aptian to earliest Paleocene). Two groups of fossils were focused on (1) leaf fossils from Zone I of the Potomac Group (Doyle and Hickey 1976; Hickey and Doyle 1977) and (2) leaf fossils that previous systematic investigations identified as possible stem-lineage relatives to extant Austrobaileyales and Chloranthales, referred hereafter as austrobaileyoids and chloranthoids, respectively (Appendix II, online). Appendix III (online) presents evidence for stratigraphic ages and systematic placements for the fossils measured. 
Maximum Photosynthetic Rates and Stomatal Conductances.-To test how leaf venation and stomatal pore structure related to photosynthetic gas exchange, water vapor and $\mathrm{CO}_{2}$ exchange fluxes were measured with a photosynthesis infrared gas analyzer (LiCOR 6400XT, Li-COR Biosciences, Lincoln, NB, United States of America). We chose 30 basal angiosperm species to obtain a broad sampling of phylogenetic and ecological diversity (Appendix I, online) (Feild et al. 2004, 2009).

Stomatal water vapor conductance $\left(g_{\mathrm{m}}\right.$, mmol $\mathrm{H}_{2} \mathrm{O} \quad \mathrm{m}^{-2} \mathrm{~s}^{-1}$ ) and photosynthetic capacity $\left(P_{\mathrm{C}}, \mu \mathrm{mol} \mathrm{CO} \mathrm{CO}^{-2} \mathrm{~s}^{-1}\right)$ were measured on clear mornings (0900-1130 h) to: (1) avoid heterogeneities on leaf gas exchange due to passing clouds, (2) ensure leaves were dry, and (3) ensure that maximal stomatal opening and light-induction of photosynthesis occurred before midday stomatal closure. Microclimate around leaves during measurements was controlled at $25 \pm 1.5^{\circ} \mathrm{C}, 1300 \mu \mathrm{mol}$ quanta $\mathrm{m}^{-2} \mathrm{~s}^{-1}$ photosynthetic photon flux density (PPFD), vapor pressure deficit (VPD) between 0.9 and $1.1 \mathrm{kPa}$, and $380 \pm 5 \mu \mathrm{L} \mathrm{L}^{-1}$ $\mathrm{CO}_{2}$. The light intensities provided saturated photosynthesis but did not induce photoinhibition (Feild et al. 2004). Measurements under these optimal conditions served as the photosynthetic and stomatal conductance maxima attainable for a species. Photosynthetic gas exchange capacity for each species was based on a sample of five undamaged and fully expanded leaves from each of five individuals.

Vein Density $\left(D_{\mathrm{v}}\right)$ of Extant and Fossil Leaves to Calculate Leaf Gas Exchange Capacity.-Vein density is the length of veins ramifying in a given amount of leaf area $\left(\mathrm{mm} \mathrm{mm}^{-2}\right)$. Data from living plants demonstrated that photosynthetic capacity and stomatal conductance to water vapor can be predicted from $D_{\mathrm{v}}$ (Brodribb et al. 2007; Boyce et al. 2009; Brodribb and Feild 2010; McKown et al. 2010). $D_{\mathrm{v}}$ is a major determinant of leaf $\mathrm{CO}_{2} / \mathrm{H}_{2} \mathrm{O}$ exchange because water transport and photosynthetic gas exchange are coupled (Sperry 2003). Leaf hydraulic capacity is set by vein structure because increased vein branching brings xylem tissues that are specialized for water transport closer to the sites of water evaporation in the leaf (Brodribb et al. 2007; McKown et al. 2010). Hence, $D_{\mathrm{v}}$ defines the hydraulic supply limit of water vapor exchange that secondarily dictates maximum $\mathrm{CO}_{2}$ assimilation by leaves (Brodribb et al. 2007; Brodribb and Feild 2010).

$D_{\mathrm{v}}$ of extant taxa was measured on leaves cleared using sodium hydroxide, sodium hypochlorite, and heat (Hudson et al. 2010). Veins were stained in safranin and measured using an upright microscope over approximately $6 \mathrm{~mm}^{2}$ of area (Axio-Imager, CarlZeiss, Germany). Digital images were captured with an AxioCam camera (Carl-Zeiss, Germany) and processed using ImageJ (http://rsb.info.nih.gov/ij/; NIH, Bethesda, Maryland) to measure $D_{\mathrm{v}}$. $D_{\mathrm{v}}$ was measured on compression fossils by tracing vein lengths using ImageJ. Images were obtained with a digital camera and macro lens (Nikon D300S with Nikkor $60 \mathrm{~mm}$ lens, Nikon, Japan) or by digitizing $10.1 \times 12.7 \mathrm{~cm}$ photographic negatives and prints of fossils at $600 \mathrm{dpi}$. Three $D_{\mathrm{v}}$ measurements on each sampled fossil for each species were taken. Only fossils with well-preserved venation were sampled (Fig. 1). Details on how fossils were selected for measurements are provided in Appendix III (online).

We used a published model to reconstruct photosynthetic capacity $\left(P_{\mathrm{C}}\right)$ and maximum stomatal conductance to water vapor of fossil leaves from $D_{\mathrm{v}}$ (see Brodribb et al. 2007; Brodribb and Feild 2010). The model assumes that under non-limiting conditions of soil water availability, maximum leaf hydraulic conductance $\left(K_{\text {leaf }}\right)$ can be calculated from the distance water must flow from the vein terminals to the sites of evaporation $\left(d_{m}\right.$; Brodribb et al. 2007). By knowing $K_{\text {leaf }}$ one can calculate maximum stomatal conductance to water vapor from vein density $\left(g_{\mathrm{c}}{ }^{\mathrm{VEIN}}\right)$, which provides a basis for calculating maximum leaf $P_{C}$. To emphasize the impact of vein evolution on gas exchange, we used fixed concentrations of $\mathrm{CO}_{2}$ and $\mathrm{O}_{2}$ (current ambient concentrations) to reconstruct photosynthetic capacity. Our emphasis was on diffusive-hydrodynamic constraints to leaf gas exchange rather than biochemical constraints upon photosynthesis such as maxi- 
A

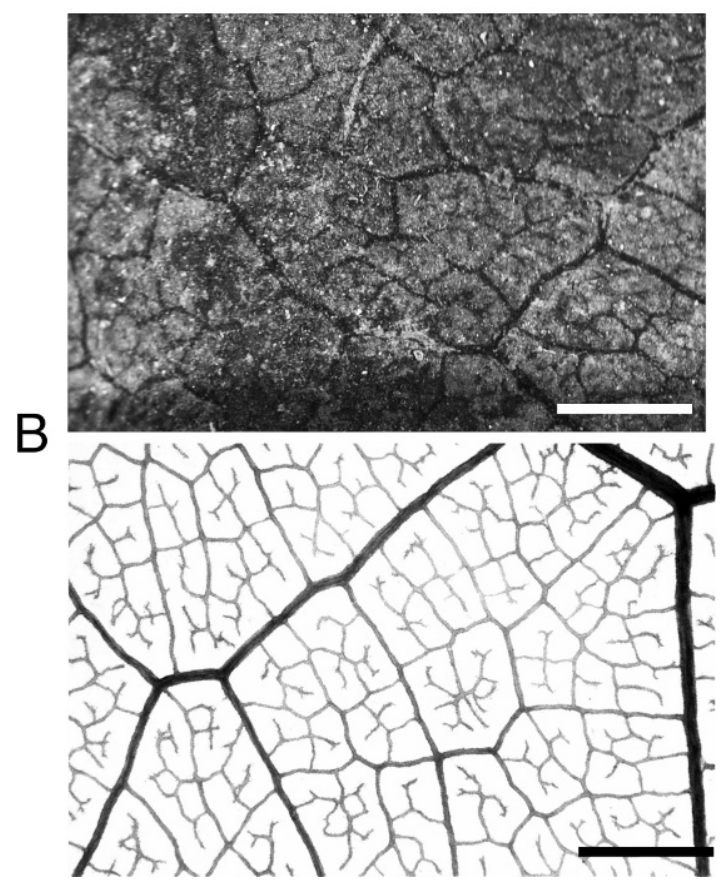

FIGURE 1. Comparison of fossil preservation of minor veins in Ficophyllum crassinerve (USNM192353), a putative austrobaileyoid stem-lineage with a vein density of $3.52 \mathrm{~mm} \mathrm{~mm}^{-2}$ (A) and a sun leaf of extant Amborella trichopoda with vein density of $3.77 \mathrm{~mm} \mathrm{~mm}^{-2}$ (B). Scale bars, $1.5 \mathrm{~mm}$.

mum electron transport and carboxylation rates. These enzymatic processes are not preserved in fossils. Instead of attempting a highly uncertain reconstruction leaf gas exchange capacities across an uncertain range of cross-varying Cretaceous ambient $\mathrm{CO}_{2}$ and $\mathrm{O}_{2}$ concentrations (McElwain et al. 2005; Fletcher et al. 2008; Barclay et al. 2010; Glasspool and Scott 2010; Royer 2010), atmospheric gas concentrations were constrained to allow a comparison of gas exchange capacities under standard conditions. Parameters for VPD and water potential gradient across the leaf were set at $1 \mathrm{kPa}$ and $-0.5 \mathrm{MPa}$, respectively. These physiological conditions are associated with maximal gas exchange capacity for terrestrial basal angiosperms (Feild et al. 2009). Leaf thickness affects estimates of maximum $\mathrm{CO}_{2} / \mathrm{H}_{2} \mathrm{O}$ gas exchange by varying $d_{\mathrm{m}}$ (Brodribb et al. 2007). Thus, leaf gas exchange capacities were calculated at lower $(70 \mu \mathrm{m})$ and upper
$(140 \mu \mathrm{m})$ ends for the range of vein-epidermal thicknesses for mesophytic angiosperm leaves (Brodribb et al. 2007; D. S. Chatelet and T. S. Feild unpublished data 2009). This procedure was applied because leaf thickness cannot be measured in compression fossils.

Measurements of Stomatal Apparatus Geometry in Living and Fossil Leaves and Calculation of Maximum Stomatal Conductance to Water Vapor.-An accepted equation to calculate the maximum diffusive conductance of the stomata $\left(g_{\text {stoma }}\right)$ was used (Parlange and Waggoner 1970; Van Gardenigen et al. 1989; Kaiser 2009):

$$
\begin{aligned}
g_{\text {stoma }}=1 /\{[(d / \pi * a * b)] \\
+\ln (4 a / b) / \pi * a] / D * N\}
\end{aligned}
$$

where $a=$ guard cell pore length $/ 2, b=$ guard cell pore width $/ 2, d=$ guard cell pore depth; $D=$ diffusivity of water vapor in air, $N$ $=$ guard cell density. Measurements of $d$ were made on cross-sections of FAA fixed leaves embedded in plastic resin (JB-4, Polysciences Inc., Warrington, Pennsylvania), and sectioned at $5-\mu \mathrm{m}$ thickness on a rotary microtome (RM2245, Leica Microsystems, Germany). From each species, 20 guard cell pores were imaged at $400 \times$ and measured with ImageJ. $a$ and $N$ were determined on macerated cuticles stained in safranin. Cuticles were macerated using acetic acid and hydrogen peroxide. We measured five $4-\mathrm{mm}^{2}$ sheets of cuticle for $N$ at $200 \times$. Geometric landmarks for assessing guard cell pore length and depth followed previous criteria (Lawson et al. 1998). We assumed that maximum guard cell width $(b)$ was approximated by one-third of the guard cell pore length (Osborne et al. 2004). Using the length and width of the stomatal pore, and approximating the pore as an ellipse, we calculated stomatal pore area at maximal aperture $(S P A$, $\left.\mathrm{m}^{2}\right)$.

The stomata of extant basal angiosperms and the fossil stomata investigated possessed prominent peristomatal rims over the guard cell pores (Upchurch 1984a,b, 1995). Vestibules could lengthen the diffusional path length from the stomatal pore to the bulk phase. As a result, the accuracy of equation 
(1) will be affected. The calculated maximum conductance of the stomatal pore complex $\left(g_{c}\right.$ STOMA $\left.\mathrm{mmol} \mathrm{m}^{-2} \mathrm{~s}^{-1}\right)$ to water vapor is:

$$
g_{\mathrm{c}} \text { STOMA }=1 /\left(r_{\text {stoma }}+r_{\text {vestibule }}\right)
$$

where $r_{\text {stoma }}$ is the resistance of the stoma and $r_{\text {vestibule }}$ is the resistance of the vestibule atop a stoma. The resistances of each term were calculated by substituting the length, width, and depth of the vestibule or the stoma into equation (1). Vestibule depth was measured at $400 \times$ from the same cross-sections as described above, and vestibule length and width determined from cuticle macerations at $400 \times$. To improve the accuracy of vestibule geometry measurements, we observed stomatal vestibules of some species with scanning electron microscopy on critically dried leaves (observations not shown). An approximation of the cuticular vestibule and stomatal pore resistors as additive in series makes three assumptions: (1) the architectures can be approximated as connected pores of simple cylindrical geometry; (2) diffusion within the two components does not involve exchange through the walls of each; and (3) other resistors to water vapor diffusion, such as internal cuticle and intercellular conductance, are not significant. Assumptions one and two are reasonable because vestibules consist of a thick cuticle that is likely to be impermeable to water vapor. Assumption three is valid because maximum conductance was calculated (Kaiser 2009).

On fossil leaf cuticles, measurements were made on previous cuticular preparations from four localities (Appendix III, online) (Upchurch 1984a,b, 1995; Upchurch and Dilcher 1990). Guard cell pore length as well as the length and width of the vestibule aperture were measured at $400 \times$. Guard cell width was approximated as one-third of the pore length. The taxon means are from ten stomata. Stomata pore or vestibule depths could not be measured on the prepared fossil cuticles. However, stomatal pore depth correlated with stomatal pore length $\left(n=113 ; r^{2}\right.$ $=0.87$ ) across a broad range of stomatal size (i.e., $18 \mu \mathrm{m}$ to $\sim 100 \mu \mathrm{m}$ in maximum length [D. S. Chatelet unpublished data 2010]). Thus, stomatal length measurements were used to calculate stomatal pore depth. Stomatal vestibule depth of fossil leaf cuticles was approximated in the calculations as the average depth $(5.48 \pm 2.6 \mathrm{SD} \mu \mathrm{m}, n=113)$ found across all of the extant angiosperms sampled.

Phylogenetic Analyses.-To compare leaf fossils to reconstructed nodes of trait evolution across extant angiosperm phylogeny, we assembled a composite phylogenetic tree by grafting species-level trees onto two wellsupported backbone topologies using Mesquite version 2.6 (Maddison and Maddison 2008). The species-level phylogenies included the following clades: Chloranthales, Illiciaceae, Schisandraceae, Trimenia, and Nymphaeales (Jansen et al. 2007; Moore et al. 2007; Saarela et al. 2007; Endress and Doyle 2009; Feild et al. 2009). Published consensus trees were used, and the polytomies treated as soft. The composite tree was pruned to leave the species sampled.

Ancestral state values for functional traits were reconstructed using weighted squaredchange parsimony over species terminals using Mesquite. This method minimizes the sum of squared change along all branches of the tree to reconstruct the values of internal nodes from the trait values of the species' terminals (Maddison and Maddison 2008). For species with sun and shade leaves, ancestral state trait reconstructions were performed using the maximum trait values. Then, a separate analysis was run using the average of sun and shade values to define a species trait value. In cases where the phylogenetic relations were uncertain, Mesquite was used to randomly resolve phylogenetic relations within clades (100 times), and the trait values for nodes within the tree were averaged (Appendix IV, online).

\section{Results}

Leaf Venation Density and Gas Exchange Capacity in Extant and Extinct Leaves.-Leaf photosynthetic capacity $\left(P_{\mathrm{C}}\right)$ and maximum stomatal conductance to water vapor $\left(g_{\mathrm{m}}\right)$ increased linearly with increasing vein density $\left(D_{\mathrm{v}}\right.$; Fig. 2A,B). Nymphaeales, however, represented exceptions with high $P_{\mathrm{C}}$ and $g_{\mathrm{m}}$ but with comparatively low $D_{\mathrm{v}}$ (Fig. 2A). Across all species, $P_{\mathrm{C}}$ increased with $g_{\mathrm{m}}$ (Fig. 2C). 
A

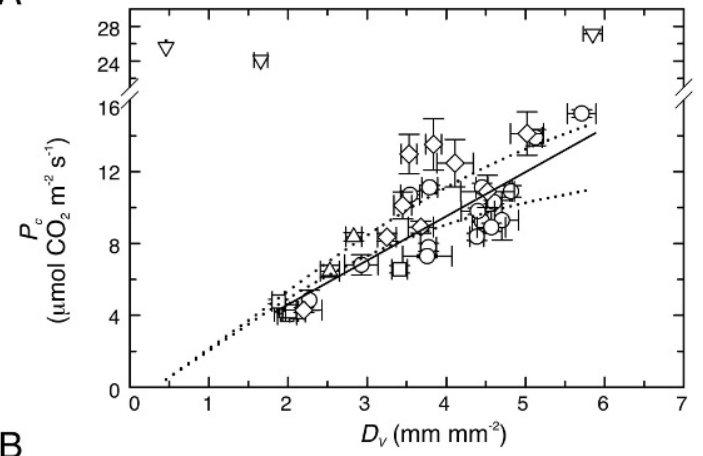

B

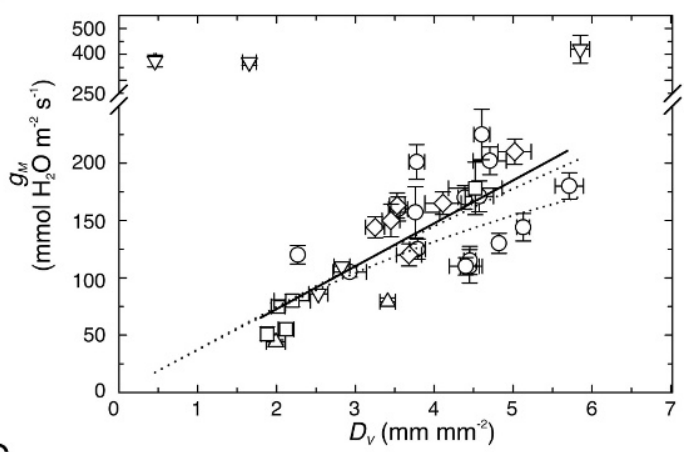

C

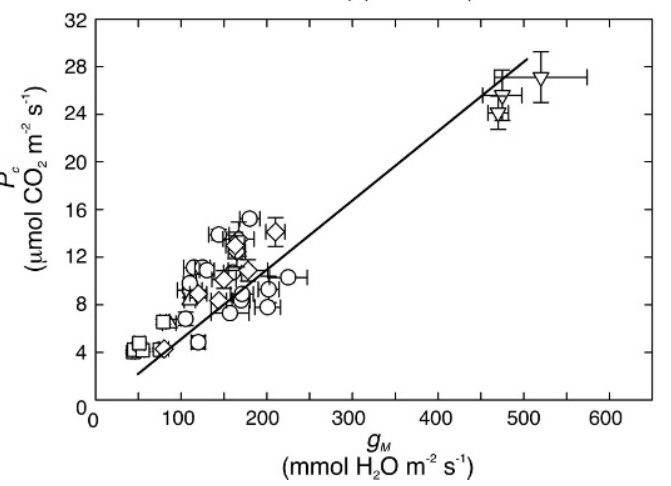

FIGURE 2. Coordination of structure-function relations of the venation system and leaf gas exchange capacity across 35 extant basal angiosperm species. A, Relation between leaf photosynthetic capacity $\left(P_{\mathrm{C}}, \mu \mathrm{mol} \mathrm{CO}_{2} \mathrm{~m}^{-2} \mathrm{~s}^{-1}\right)$ and

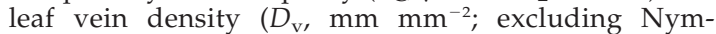
phaeales, $\left.y=2.444 x, r^{2}=0.69\right)$. B, Relation between measured maximum stomatal conductance to water vapor $\left(g_{\mathrm{m}} \mathrm{mmol} \mathrm{H}_{2} \mathrm{O} \mathrm{m} \mathrm{m}^{-2} \mathrm{~s}^{-1}\right)$ and $D_{\mathrm{v}}\left(y=36.1 x, r^{2}=\right.$ 0.62). C. Relation of $P_{C}$ to $g_{\mathrm{m}}$ (with Nymphaeales, $y=$ $0.059 x, r^{2}=0.79$; excluding Nymphaeales, $y=0.065 x, r^{2}=$ 0.42). Standardized measurement environmental conditions are described in "Methods." Symbols denote growth forms for A-C: $\bigcirc$, shrubs and trees; $\diamond$ lianas; $\square$, sub-shrubs; $\triangle$, terrestrial herbs; $\nabla$, floating leaves of aquatic Nymphaeales herbs. Points are the averages of three observations made on five to ten leaves per species, and error bars denote standard deviation about the mean. The dotted lines in A and B refer to modeled photosynthetic capacities and maximum stomatal conductances based on vein density at 140 and $70 \mu \mathrm{m}$ leaf thicknesses. Species information and data are provided in Appendix I (online).
Vein densities of extant Chloranthales ranged from $1.62 \mathrm{~mm} \mathrm{~mm}^{-2}$ for shade leaves of Hedyosmum orientale to $5.06 \mathrm{~mm} \mathrm{~mm}^{-2}$ for sun leaves of Ascarina maheswari. Extant Austrobaileyales $D_{\mathrm{v}}$ ranged from $1.94 \mathrm{~mm}$ $\mathrm{mm}^{-2}$ for shade leaves of Austrobaileya scandens to $6.35 \mathrm{~mm} \mathrm{~mm} \mathrm{~mm}^{-2}$ for sun leaves of Kadsura heteroclita. Mean $D_{\mathrm{v}}$ of all Zone I fossil species measured from the Potomac Group extended over approximately $50 \%$ of the extant terrestrial basal angiosperm range, varying from $2.8 \mathrm{~mm} \mathrm{~mm}^{-2} \pm 0.36 \mathrm{SD}$ in Proteaephyllum reniforme to $4.1 \mathrm{~mm} \mathrm{~mm}^{-2} \pm$ 0.18 SD in "Sapindopsis" elliptica. The mean for Zone I leaves $\left(3.38 \mathrm{~mm} \mathrm{~mm}^{-2} \pm 0.35 \mathrm{SD} ; n=\right.$ 12 species) did not differ significantly from the extant terrestrial basal angiosperm mean (results not shown). Zone I fossil leaves also exhibited $D_{\mathrm{v}}$ values similar to the reconstructed $D_{\mathrm{v}}$ trait values over the base of extant angiosperm phylogeny (Fig. 2; Supplemental Table 1 and Fig. S1).

Vein densities for chloranthoids averaged $3.58 \mathrm{~mm} \mathrm{~mm} \mathrm{~mm}^{-2} \pm 0.62 \mathrm{SD}(n=11$ species; Fig. 3) and ranged from $2.47 \mathrm{~mm} \mathrm{~mm}^{-2} \pm 0.08$ $\mathrm{SD}$ in Reynoldsiophyllum nebrascense (Rose Creek, Late Albian) to $4.61 \mathrm{~mm} \mathrm{~mm}^{-2} \pm 0.46$ in Crassidenticulum cracendentis (Courtland, Cenomanian). $D_{\mathrm{v}}$ of austrobaileyoid leaves averaged $3.61 \mathrm{~mm} \mathrm{~mm}^{-2} \pm 0.46 \mathrm{SD}(n=5)$ ranged from $3.12 \mathrm{~mm} \mathrm{~mm}^{-2} \pm 0.21 \mathrm{SD}$ in the Fredericksburg sample of Eucalyptophyllum oblongifolium (Upper Zone I, Potomac Group) to $4.36 \mathrm{~mm} \mathrm{~mm}^{-2} \pm 0.32 \mathrm{SD}$ in Longstrethia varidentata (latest Albian, Rose Creek; Fig. 3). In addition, mean vein densities for chloranthoids and austrobaileyoids did not differ significantly (results not shown). No trend in $D_{\mathrm{v}}$ across the sampled fossil species was observed through time (Fig. 3). Finally, maximum $\mathrm{CO}_{2}$ exchange and stomatal conductances to water vapor calculated from vein density $\left(g_{c}{ }^{\text {VEIN }}\right)$ for chloranthoid and austrobaileyoid species through time fell within the 10th and 90th percentiles' extant species and reconstructed ancestral node trait values over the base of extant phylogeny (Fig. 3).

Stomatal Pore Anatomy and Gas Exchange Capacity in Leaves of Extant and Extinct Species.-Stomatal size measured on fossil cuticles encompassed approximately $60 \%$ of 

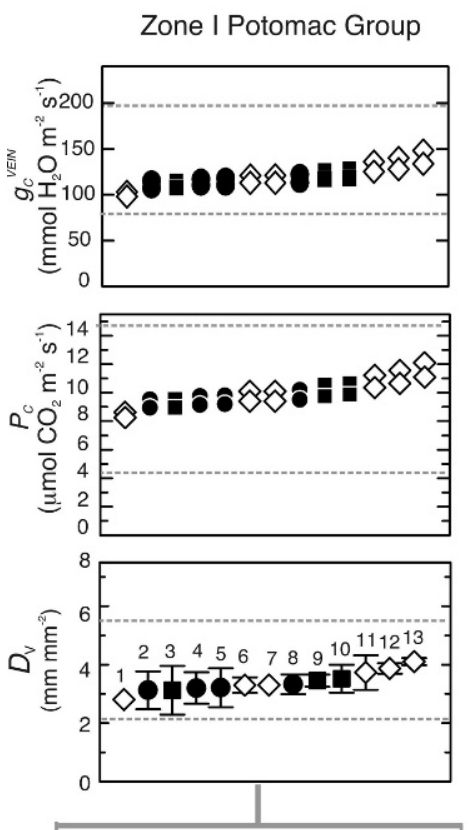

Braun Ranch, Rose Creek, Hoisington III

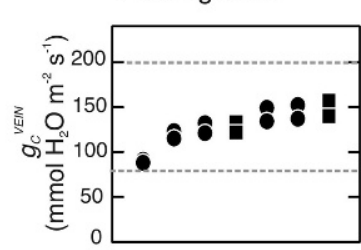

Courtland
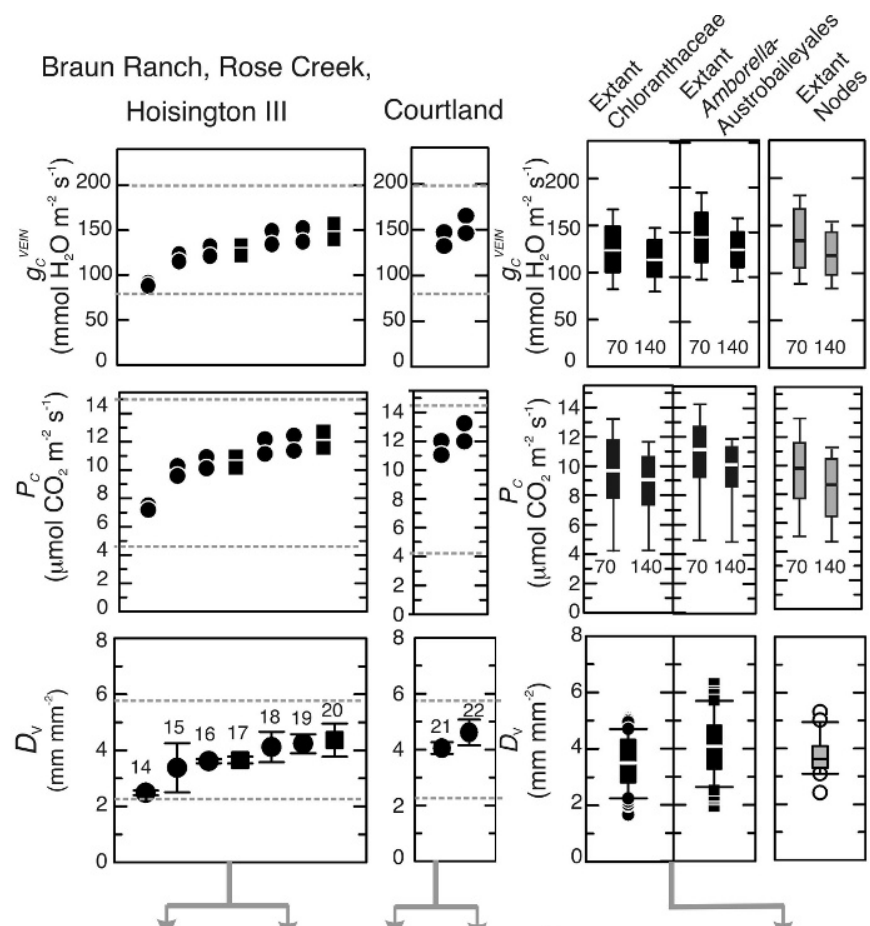

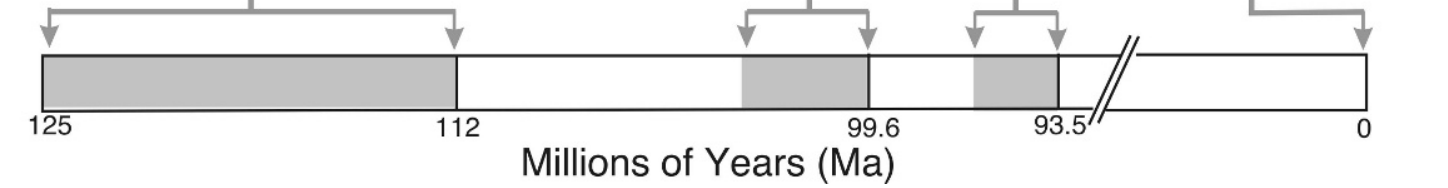

Figure 3. Leaf vein density $\left(D_{\mathrm{v}}, \mathrm{mm} \mathrm{mm}^{-2}\right)$ and leaf $\mathrm{CO}_{2} / \mathrm{H}_{2} \mathrm{O}$ gas exchange capacities (photosynthetic capacity, $P_{\mathrm{C}}$, $\mu \mathrm{mol} \mathrm{CO}_{2} \mathrm{~m}^{-2} \mathrm{~s}^{-1}$ and stomatal conductance to water vapor, $g_{\mathrm{c}}{ }^{\mathrm{VEIN}}$ ) calculated from a coupled venation hydraulicphotosynthetic model with $\mathrm{CO}_{2}$ concentration set at $380 \mu \mathrm{L} \mathrm{L}^{-1} \mathrm{CO}_{2}$ for early angiosperm leaf fossils. Gray regions on the timescale refer to the stratigraphic age range for the fossil localities (Zone I Potomac Group [lower upper Aptian], Braun Ranch and Rose Creek [upper Albian], Courtland [Cenomanian]). $P_{C}$ and $g_{c}{ }^{\text {VEIN }}$ were parameterized using two vein-to-epidermal hydraulic distances from $70 \mu \mathrm{m}$ to $140 \mu \mathrm{m}$ to produce a span of predicted values encompassing the likely morphological variability in the thicknesses of angiosperm leaves. The two points for $P_{\mathrm{C}}$ and $g_{\mathrm{C}}$ VEIN for each fossil leaf taxon reflect these values. Symbols refer to previously hypothesized systematic affinities of fossil leaves: stemlineage austrobaileyoids $(\boldsymbol{\square})$ and chloranthoids $(\mathbf{O})$, and fossil leaves of uncertain systematic placement $(\diamond)$. Numbers refer to the species: 1, Proteaephyllum reniforme; 2, Celastrophyllum latifolium; 3, Eucalyptophyllum oblongifolium Fredericksburg sample; 4, Celastrophyllum sp. Drewry's Bluff; 5, Drewry's Bluff Leaf Type \#1 (Moutonia); 6, Celastrophyllum sp. (C. obovatum); 7, Vitiphyllum multifidum; 8, Quercophyllum tenunerve; 9, Eucalyptophyllum oblongifolium Drewry's Bluff; 10, Ficophyllum crassinerve; 11, Rogersia angustifolia; 12, cf. Ficophyllum; 13, Sapindopsis elliptica; 14, Reynoldsiophyllum nebrascense; 15, Crassidenticulum landiase; 16, Crassidenticulum decurrens Braun Ranch samples; 17, Longstrethia aspera; 18, Dennsineroum kaulii Rose Creek samples; 19, Crassidenticulum decurrens Rose Creek samples; 20, Longstrethia varidentata; 21, Densinervum kaulii Courtland sample; 22, Crassidenticulum cracendtis. The dashed lines across the three fossil data panels indicate the 10th and 90th percentiles of $g_{\mathrm{c}}^{\text {sTOMA }}$ across the extant species. The box plots depict the variation within extant clades with the bottom and top of the box indicating the 25th and 75th percentiles, respectively, the two whiskers the 10th and 90th percentiles, respectively, and the horizontal line within the box, the median value. Symbols beyond the whiskers are outliers.

the stomatal size and density range for extant Austrobaileyales and Chloranthales (Fig. 4A). Across extant terrestrial basal angiosperms (excluding the sun leaves of Kadsura coccinea that possessed unusually large stomata), maximum calculated stomatal conductance from pore geometry $\left(g_{c}^{\text {STOMA }}\right)$ increased with maximal stomatal pore area (SPA) for diffusive exchange (Fig. 4B; $g_{\mathrm{c}}{ }^{\text {STOMA }}=30.15 S P A-$
53.57; $\left.n=104 ; r^{2}=0.8\right)$. Similarly, $g_{c}^{\text {STомA }}$ increased with greater $S P A$ in fossil cuticles $\left[\left(g_{c}{ }^{\text {STOMA }}\right)=34.36(S P A)-75.73, n=10, r^{2}=\right.$ 0.82; Fig. 4B].

Maximum calculated stomatal conductance from pore geometry ranged from $105 \mathrm{mmol}$ $\mathrm{H}_{2} \mathrm{O} \mathrm{m} \mathrm{m}^{-2} \mathrm{~s}^{-1}$ in the austrobaileyoid Ficophyllum crassinerve to $327 \mathrm{mmol} \mathrm{H}_{2} \mathrm{O} \mathrm{m} \mathrm{m}^{-2} \mathrm{~s}^{-1}$ in Celastrophyllum latifolium (Figs. 4B, 5). Over 
A

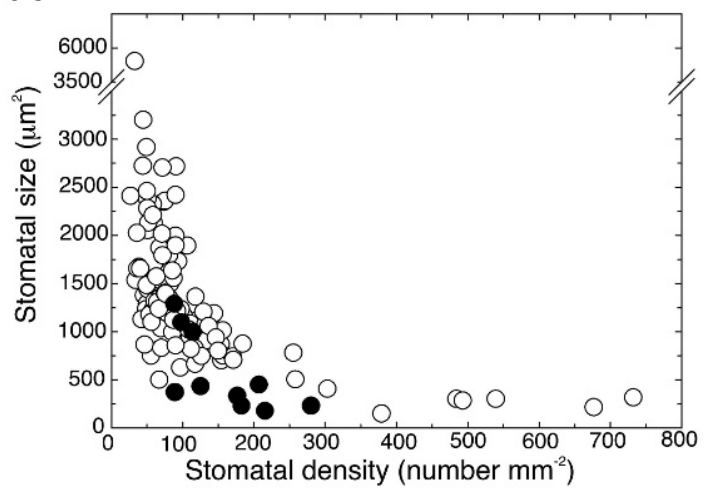

$\mathrm{B}$
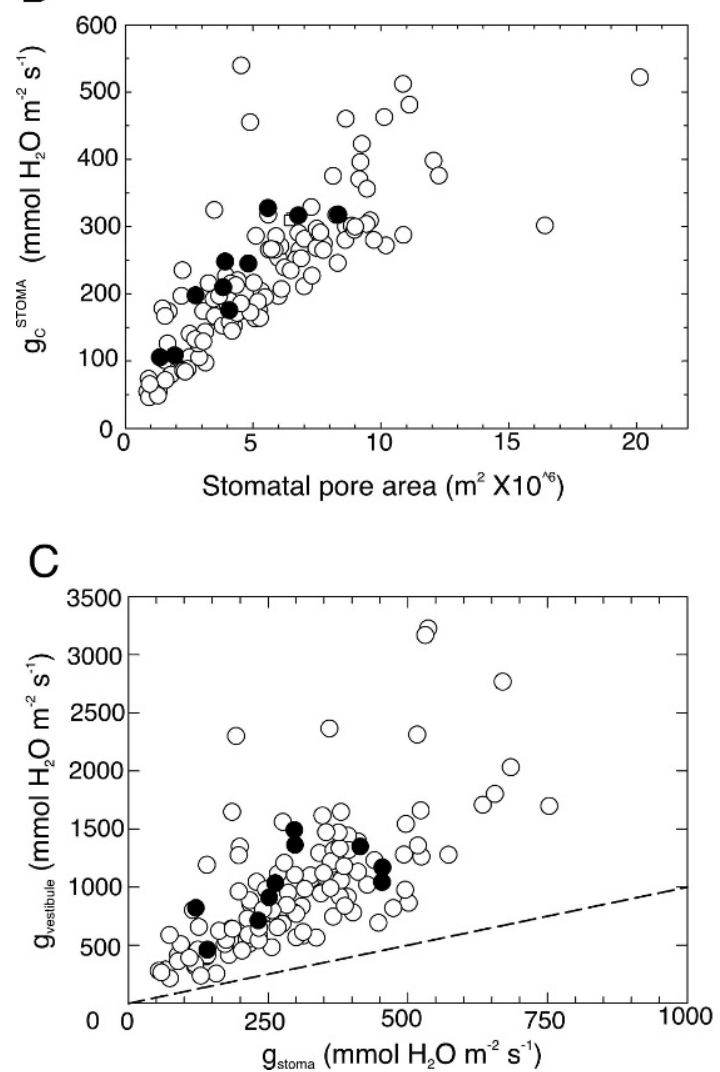

FIGURE 4. Relations among stomatal morphology and maximum stomatal conductance to water vapor (mmol $\mathrm{H}_{2} \mathrm{O} \mathrm{m} \mathrm{m}^{-2} \mathrm{~s}^{-1}$ ) for extant basal angiosperms and fossil cuticles. A, Stomatal size $\left(\mu \mathrm{m}^{2}\right)$ versus stomata density (number $\mathrm{mm}^{-2}$ of leaf area) for extant basal angiosperms and fossil cuticles. B, Maximal stomatal conductance to water vapor calculated from stomatal pore dimensions ( $g_{\mathrm{c}}$ STOMA, $\mathrm{mmol} \mathrm{H}_{2} \mathrm{O} \mathrm{m}^{-2} \mathrm{~s}^{-1}$ ) versus stomatal pore surface area $\left(\mathrm{m}^{2} \times 10^{6}\right)$ across extant and extinct fossil cuticles. C, Calculated maximal water vapor conductance of the stomatal vestibule $\left(g_{c}\right.$ vESTIBULE, mmol $\left.\mathrm{H}_{2} \mathrm{O} \mathrm{m}^{-2} \mathrm{~s}^{-1}\right)$ versus $g_{c}$ STOMA for fossil and extant cuticles. The dashed line shows the one-to-one relation. $\bigcirc$, extant basal angiosperm leaves the fossil species sampled, no time-dependent pattern in $g_{c}$ STOMA was found (Fig. 5). Maximum calculated stomatal conductance from pore geometry of fossil cuticles nested within the range of extant species (Figs. 4B, 5). Consistent with the result that SPA drives much of $g_{\mathrm{c}}^{\text {STOMA }}$, water vapor conductances of stomatal vestibules were three to six times greater than calculated stomatal conductances of just the stomata pore across all of the extant and extinct leaves sampled (Fig. 4C).

$g_{c}^{\text {STOMA }}$ was related positively to maximum stomatal conductance $\left(g_{\mathrm{m}}\right)$ as measured by leaf gas exchange analysis across terrestrial basal angiosperm species $\left(g_{\mathrm{c}}^{\text {STOMA }}=1.632\left(g_{\mathrm{m}}\right)\right.$ $+9.04, n=30 ; r^{2}=0.64$; Fig. 6 A).$g_{c}^{\text {STOMA }}$ values, however, were greater than $g_{\mathrm{m}}$ in terrestrial basal angiosperm species (Fig. 6A). By comparison, maximal stomatal conductance to water vapor calculated from vein density $\left(g_{c}\right.$ VEIN $)$ yielded estimates closer to measured stomatal conductance maxima on extant leaves $\left(g_{\mathrm{c}}\right.$ VEIN $=0.514\left(g_{\mathrm{m}}\right)-57.56, n=$ $30 ; r^{2}=0.60$; Fig. 6A). Nymphaeales leaves, however, exhibited much greater $g_{\mathrm{m}}$ in comparison to $g_{c}$ STOMA and $g_{c}{ }^{\text {VEIN }}$ (Fig. 5B). $D_{\mathrm{v}}$ and $S P A$ were unrelated, as were $g_{c}{ }^{\text {STOMA }}$ and $g_{c}$ VEIN (Fig. 6C).

\section{Discussion}

Fossil Evidence for Low Gas Exchange Capacity in Early Angiosperm Leaves.-All Zone I Potomac Group fossil angiosperm leaves measured had structural traits related to lower gas exchange capacities, in contrast to modern ecologically dominant angiosperms. $D_{\mathrm{v}}$ values of late Aptian-early Albian fossil angiosperm leaves occurred in the narrow range of low densities found across ferns and gymnosperm clades that dominated plant communities during the Early Cretaceous (Lupia et al. 1999; Boyce et al. 2009). The uniform pattern of low vein densities across Zone I angiosperm fossil leaves contrasts with the widespread dominance of high vein

\section{$\leftarrow$}

(including Amborella, Austrobaileyales, Chloranthales, and Nymphaeales); and 0 , fossil cuticles (see Appendix II, online, for the taxa sampled). 


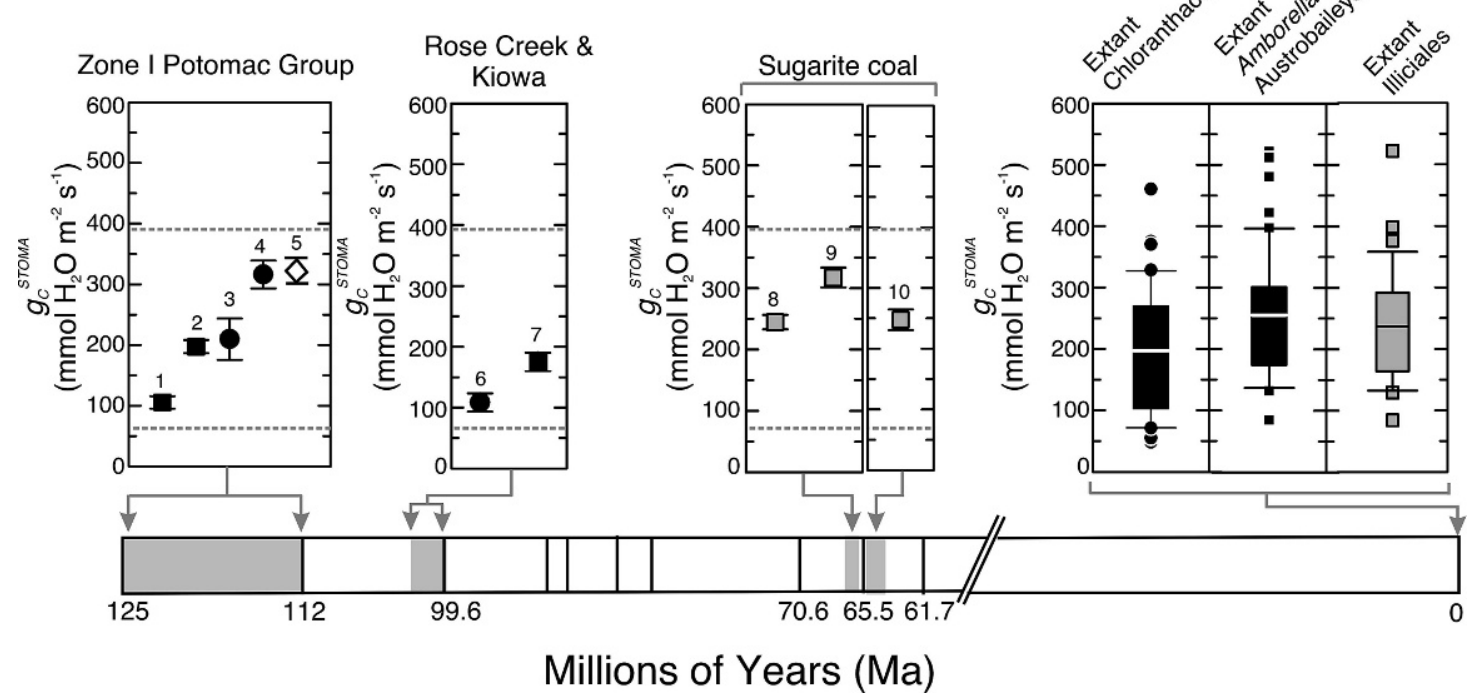

FIGURE 5. Maximum stomatal conductance to water vapor calculated from stomatal pore dimensions $\left(g_{c}^{\text {STOMA }}\right.$, mmol $\mathrm{H}_{2} \mathrm{O} \mathrm{m} \mathrm{m}^{-2} \mathrm{~s}^{-1}$ ) of fossil austrobaileyoid $(\boldsymbol{\square})$, chloranthoid (O), illicioid cuticles ( $\square$ filled gray), and of uncertain systematic placement $(\diamond)$ as compared to extant Chloranthales, Amborella-Austrobaileyales, and Illiciaceae plus Schisandraceae. Numbers refer to taxa: 1, cf. Ficophyllum; 2, Eucalyptophyllum; 3, Drewry's Bluff Leaf Type \#1; 4, Celastrophyllum sp.; 5, Celastrophyllum latifolium; 6, Moutonia; 7, Longstrethia varidentata; 8, Illiciales Type I; 9, Illiciales Type 2; 10, Protoilliciales. Gray regions on the timescale refer to the stratigraphic ages for the fossil localities ([Zone I Potomac Group [lower upper Aptian], Rose Creek and Kiowa Formation [upper Albian], and Sugarite Coal [upper Maastrichtian and lowest Paleocene]). The dashed lines across the three fossil data panels indicate the over extant range from the 10th and 90th percentiles of $g_{\mathrm{c}}^{\text {STOMA }}$. The box plots depict the variation within extant clades with the bottom and top of the box indicating the 25th and 75th percentiles, respectively, the two whiskers the 10th and 90th percentiles, respectively, and the horizontal line within the box, the median value. Symbols beyond the whiskers are outliers.

densities characterizing the vast majority of ecologically abundant angiosperms today (Boyce et al. 2009; Brodribb and Feild 2010).

The functional contrast between Zone I angiosperms and extant angiosperms becomes especially striking when regeneration habitat is controlled. Extant floodplain colonizing angiosperms from warm temperate and tropical regions, which represent ecologies thought to approximate the depositional settings for many Zone I angiosperms, exhibit vein densities ranging from 10 to $20 \mathrm{~mm} \mathrm{~mm}^{-2}$ (Doyle and Hickey 1976; Hickey and Doyle 1977; Brodribb et al. 2007; Boyce et al. 2009; Brodribb and Feild 2010). Photosynthetic capacities and stomatal conductances of these high $D_{\mathrm{v}}$ angiosperms delimit the extant limits of $\mathrm{C}_{3}$ photosynthesis in woody plants, operating close to $30 \mu \mathrm{mol} \mathrm{CO}_{2} \mathrm{~m}^{-2} \mathrm{~s}^{-1}$ and $700 \mathrm{mmol} \mathrm{H}_{2} \mathrm{O} \mathrm{m} \mathrm{m}^{-2} \mathrm{~s}^{-1}$ (Feild and Balun 2008; T. S. Feild, unpublished data from Papua New Guinea 2009-2010). By contrast, the scaling of vein density with leaf $\mathrm{CO}_{2}$ and
$\mathrm{H}_{2} \mathrm{O}$ exchange capacity across vascular plants indicates that maximum leaf gas exchange capacities of low- $D_{\mathrm{v}}$ late Aptian-early Albian angiosperms would be on average three times lower than in modern weedy riparian angiosperms photosynthesizing under physiologically optimal conditions (Fig. 3) (Brodribb et al. 2007; Boyce et al. 2009). Instead, photosynthetic and transpirational capacities modeled from veins and the stomatal pore geometry of Zone I fossil leaves as well as extant terrestrial basal angiosperm leaves equaled the low capacities of mesic shade-tolerant woody angiosperms, ferns, and some extant conifers and cycads (Körner 1995; Brodribb and Hill 1997; Brodribb and Feild 2000, 2010; Lusk et al. 2003; Brodribb et al. 2007; Feild and Balun 2008; Franks and Beerling 2009; Kaiser 2009). Other ferns (Dicranopteris, Dipteris, Gleichenia), lycopods (Lycopodium), conifers (several Pinus species), and Gnetum from sun-exposed disturbed habitats possessed higher leaf gas exchange capacities than those inferred for 
A

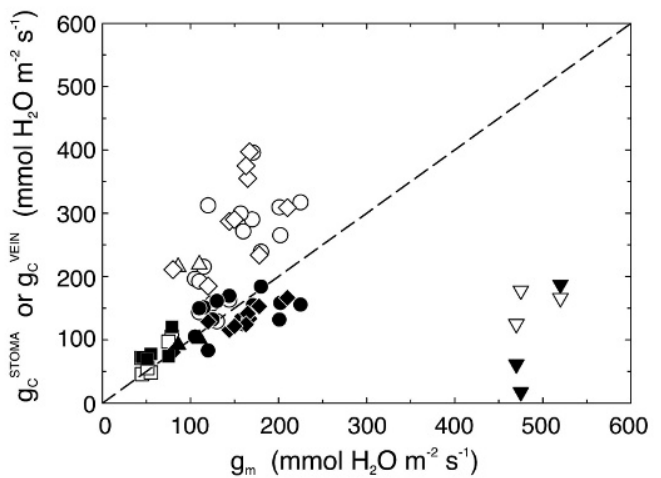

B

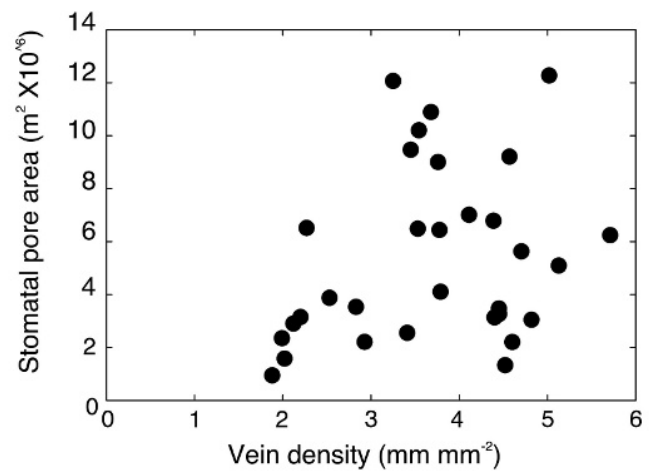

C

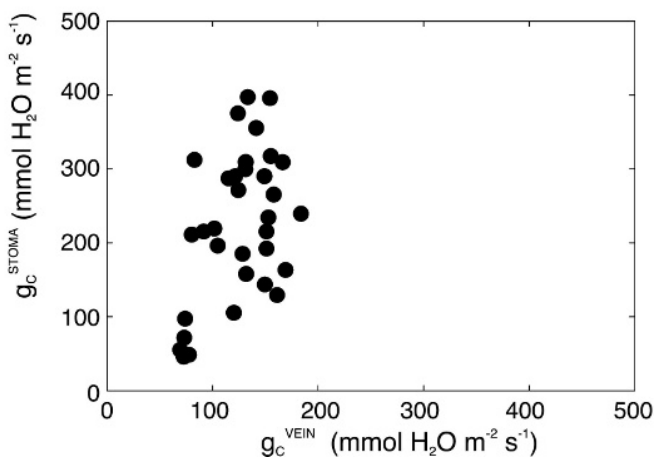

FIGURE 6. Comparisons of maximum stomatal conductances to water vapor $\left(\mathrm{mmol} \mathrm{H}_{2} \mathrm{O} \mathrm{m}^{-2} \mathrm{~s}^{-1}\right)$ as calculated from stomatal pore geometry $\left(g_{c}^{\text {STOMA }}\right)$ and vein density $\left(g_{c}{ }^{\text {VEIN }}\right)$ across extant basal angiosperm leaves with measured stomatal conductances $\mathrm{g}_{\mathrm{m}}\left(\mathrm{mmol} \mathrm{H}_{2} \mathrm{O}\right.$ $\mathrm{m}^{-2} \mathrm{~s}^{-1}$ ) and leaf structural traits. A, $g_{\mathrm{c}}^{\text {STOMA }}$ and $g_{\mathrm{c}}$ VEIN versus $g_{\mathrm{m}}$. Dashed line represents the one-to-one relation. Symbols are as in Figure 2, with open symbols denoting $g_{\mathrm{c}}$ STOMA and filled symbols denoting $g_{\mathrm{c}}{ }^{\text {VEIN }}$. B, Stomatal pore area $\left(\mathrm{m}^{2} \times 10^{6}\right)$ versus vein density $\left(\mathrm{mm} \mathrm{mm}^{-2}\right)$ over all of the extant angiosperm species sampled for gas exchange change measurements. $C, g_{c}$ STOMA versus $g_{c}$ VEIN for all of the extant angiosperm species sampled for gas exchange change measurements. Error bars have been omitted for clarity. late Aptian-early Albian angiosperms (Brodribb et al. 2007; Brodribb and Feild 2008; Feild and Balun 2008; T. S. Feild, unpublished data from New Caledonia, 2009).

Evidence for Conservatism of Low Leaf Gas Exchange Capacities in Extant Terrestrial Basal Angiosperm Leaves.-Vein densities, maximal stomatal pore areas, and calculated gas exchange capacities for all species of austrobaileyoid and chloranthoid fossil leaves sampled fell within the narrow range of low values characterizing modern diversity of extant terrestrial basal angiosperm leaves (Appendix I, online). In addition, the functional trait values of fossils nested within the range of ancestral trait values reconstructed from extant angiosperms across major earlydiverging nodes up to the common ancestor of eudicots, monocots, and magnoliids (Figs. 3, 5). Thus, our results support the hypothesis that extant Austrobaileyales and Chloranthales retain genuine functional signals of the photosynthetic capabilities found in some Early Cretaceous angiosperms.

A caveat to the view that metabolic capacities of extant basal angiosperm leaves equal those of some Early Cretaceous angiosperms is that phylogenetic relations of the hypothesized fossil austrobaileyoid and chloranthoid leaf fossils are difficult to know. A robust phylogenetic analysis of fossil leaf taxa sampled and extant angiosperms remains elusive because too few characters are preserved (Doyle 2007). Another issue is that some characters suggesting that fossils are stem-lineages to Amborella, Austrobaileyales, and/or Chloranthales, such as chloranthoid leaf teeth and low regularity of venation patterns (low leaf rank), also occur in extant magnoliids and basal eudicots (Upchurch 1984a,b; Upchurch and Dilcher 1990; Carpenter 2005). Thus, such traits are plesiomorphic for angiosperms as a whole and not diagnostic of extant basal lineages (Doyle 2007). This phylogenetic pattern is important because most magnoliids and basal eudicots possess leaves with greater $\mathrm{CO}_{2} / \mathrm{H}_{2} \mathrm{O}$ exchange capacities than Amborella, Austrobaileyales, and Chloranthales species (Brodribb and Feild 2010).

However, extant basal eudicot and magnoliid leaves of low leaf rank (defined as 1r0- 
A

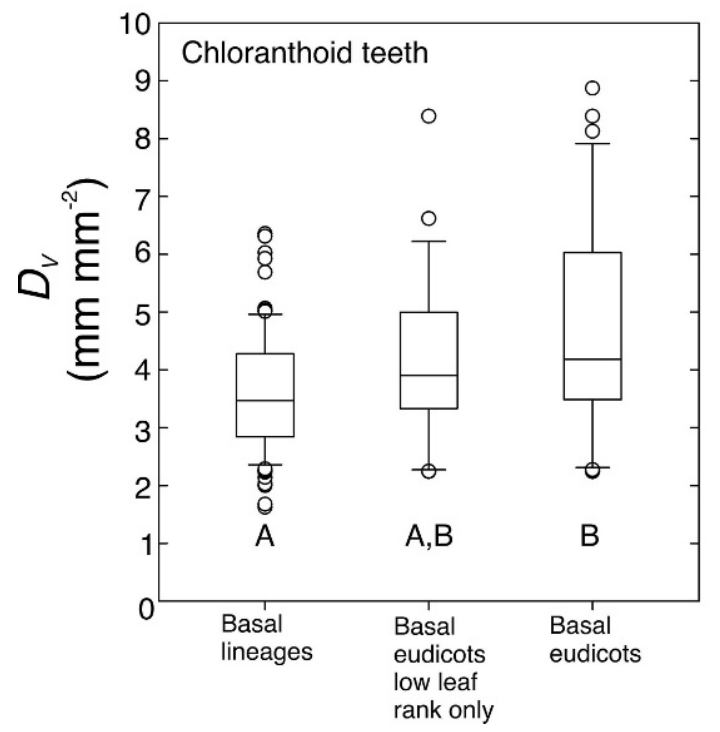

B

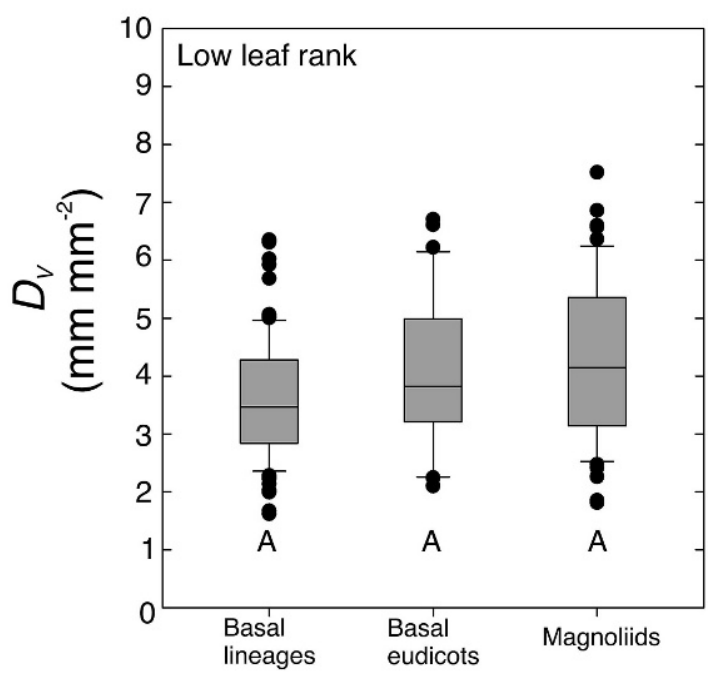

Figure 7. Vein densities $\left(D_{\mathrm{v}}, \mathrm{mm} \mathrm{mm}^{-2}\right)$ of extant basal angiosperms, 65 species of magnoliids, and basal eudicot leaves. A, Basal eudicot leaves with chloranthoid leaf teeth. B, Leaf venation architecture of low rank organization. Box plots depict the variation within extant clades with the bottom and top of the box indicating the 25th and 75th percentiles, respectively, the two whiskers the 10th and 90th percentiles, respectively, and the horizontal line within the box, the median value. Symbols beyond the whiskers are outliers. The statistical differences between group means (Student's independent $t$-test, at least $p<0.05$ ) are indicated by different letters. Basal lineage data comprise Amborella, Austrobaileyales, and Chloranthales. Basal eudicot lineages comprise Ranunculales (Ranuculaceae, Papaveraceae, Lardizabalaceae, Berberidaceae), Trochodendrales, Buxales, Gunnerales, and Proteales. Magnoliid lineages comprise Magnoliales, Canellales, Laurales, and Piperales. $D_{\mathrm{v}}$ values are taken from Brodribb and Feild (2010), and leaf rank scores from Todzia and Keating (1991).

2r3; Todzia and Keating 1991) and with chloranthoid teeth exhibited low $D_{\mathrm{v}}$ (Fig. 7A,B). Also, only a few basal eudicot species with chloranthoid teeth developed

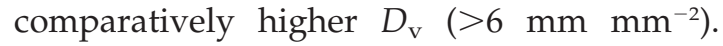
These taxa included most Gunnera species, the poikilohydric shrub Myrothamnus flabellifolius, and a few xeric-adapted Papaveraceae species. These species, however, exhibited higher leaf rank than most basal lineages and Zone I fossil leaves (Doyle and Hickey 1976; Hickey and Doyle 1977; Todzia and Keating 1991; Fuller and Hickey 2005). Thus irrespective of phylogenetic affinity, fossil angiosperm leaves of low rank, and especially if they also possess chloranthoid teeth, mark relatively low leaf gas exchange capacity. These results support a hypothesis that $D_{\mathrm{v}}$ and leaf rank correlate across angiosperms (Brodribb and Feild 2010). If increasing regularity of major vein development is associated with the ability of a higher-order venation system to more efficiently fill in the finest areoles that dictate hydraulic flux at the vein terminal (Brodribb et al. 2007; McKown et al. 2010), then leaf rank and vein density may be developmentally linked. However, more research is needed to test such a hypothesis. We do not expect that a mechanistic relationship holds between low vein density and chloranthoid teeth, because chloranthoid leaf teeth are involved in releasing sap pushed to the leaves by root pressure (Feild et al. 2005). At a minimum, our results support the hypothesis that Early Cretaceous Zone I leaves, as well as species of austrobaileyoid and chloranthoid fossils, exhibited ranges of photosynthetic and transpiration capacities analogous to extant terrestrial basal angiosperm lineages.

Evidence for Wet Habitat Adaptation in Ancient Austrobaileyoid/Chloranthoid Fossil Leaves.-Although reconstructed leaf gas exchange capacities of austrobaileyoid and chloranthoid leaf fossils compared well with their hypothesized extant descendants, similarity in low gas capacities, by itself, cannot 
diagnose whether these fossil leaves came from plants adapted to wet $\left(>2000 \mathrm{~mm} \mathrm{yr}^{-1}\right.$ rainfall) and forest understory habitats like those characterizing Amborella as well as most Austrobaileyales and Chloranthales (Feild et al. 2004, 2009). Specifying the habitat context of austrobaileyoid/chloranthoids is critical for determining how functional trait diversity in extant basal lineages bears on how the first flowering plants functioned and the selective contexts responsible for diverse hypothesized key innovations of early angiosperm success (Hickey and Doyle 1977; Retallack and Dilcher 1981; Taylor and Hickey 1996; Feild and Arens 2007; Williams 2008; Feild et al. 2009). Paleoenvironmental proxy records indicate high annual rainfalls (up to $4500 \mathrm{~mm} \mathrm{yr}^{-1}$ ) and tropical to paratropical temperatures for all of the fossils sampled (Upchurch and Wolfe 1987; Upchurch and Dilcher 1990; Upchurch 1995; White et al. 2001; Ufnar et al. 2008). However, there is tremendous variation in evaporative demand within nearly all plant communities, and therefore discerning the evaporative niches of fossil leaves demands a finer specification of canopy position (Feild et al. 2004).

Across extant basal angiosperms, low vein density and stomatal pore area signal large hydraulic constraints on photosynthesis and whole plant function, and, therefore, occurrence in wet low-evaporative-demand habitats. Strong coupling between veins and habitat occurs in basal angiosperms because these taxa cannot overcome the constraints of high xylem hydraulic resistance by operating at large drops in water potential (i.e., tolerate high drought stress) from the soil to leaf to drive high transpiration (Sperry et al. 2007; Feild et al. 2009). Instead, leaves of extant basal angiosperms wilt and the stem xylem vasculatures become embolized at modest drought stress (Sperry et al. 2007; Feild et al. 2009). Thus, to determine if austrobaileyoid and chloranthoid leaves managed hydraulic function differently than extant relatives, a knowledge of their water stress physiology is necessary. In addition, how such processes interacted with environmental conditions that have no modern analog-particularly high $\mathrm{CO}_{2}$ and $\mathrm{O}_{2}$ during the Cretaceous, which vary the amount of leverage that vein density and water-use efficiency exert on whole plant function and ecological distribution-must be considered (Sperry 2003; McElwain et al. 2005; Brodribb and Feild 2010).

A key piece of structural evidence pointing to low drought-stress tolerance in austrobaileyoids and chloranthoids is that several of these fossils possess glandular chloranthoid leaf teeth (Hickey and Doyle 1977; Upchurch 1984a,b, 1995; Upchurch and Dilcher 1990; Wang and Dilcher 2006). In extant basal angiosperms, chloranthoid leaf teeth release guttation sap during root pressure, which pressurizes the xylem (Feild et al. 2005). Root pressure occurs when the soil is at full hydration and the atmosphere saturated with water vapor-conditions that are fleeting in all but the wettest terrestrial habitats (Sperry 2003). Nonetheless, root pressure is an essential mechanism for restoring lost xylem transport capacity following drought by refilling embolized conduits across terrestrial basal angiosperms (Sperry et al. 2007). Therefore, we hypothesize that Early Cretaceous angiosperms with chloranthoid teeth likely guttated and had low drought tolerance. Because of their low vein density and stomatal pore area, such leaves are predicted to have occurred in wet zones of low transpirational pull.

Austrobaileyoid fossils, some of which lack chloranthoid teeth, were also likely adapted to damp, low-evaporation habitats because they possessed large stomatal vestibules (Upchurch 1984a,b, 1995). Stomatal vestibules do not act as anti-transpirants (Fig. 4C), but instead decrease leaf surface wettability (Schönherr and Bukovac 1972; Feild et al. 2005, 2009). Vestibules in other plants have been demonstrated to keep guard cell pores from being drowned by continuous water films formed over the cuticle during high-humidity condensation and heavy rainfall, which otherwise inhibit $\mathrm{CO}_{2}$ uptake, favor fungal invasion, and leach nutrients by excessive cuticle hydration (Schönherr and Bukovac 1972; Feild et al. 2005). The widespread pattern of large, lowdensity stomata found across extant terrestrial basal angiosperms and austrobaileyoid/chloranthoid fossils suggests that these leaves share 
slow stomatal response kinetics and low optimization of long-term carbon gain with respect to water loss-functional traits of leaves adapted to wet humid zones (Appendix I, online) (Franks and Beerling 2009). In the future, measurements of tracheary element thickness-to-span ratio in leaf veins to quantify tension-induced implosion resistance may offer a direct window on the hydraulic and drought-stress limits of early angiosperm leaves (Blackman et al. 2010). At present, interpretations of the function of fossil leaf structure are consistent with the hypothesis that austrobaileyoid and chloranthoid fossil leaves occurred in wet, very humid habitats such as underneath a canopy of non-angiosperms.

A remaining question is how several of the low- $D_{\mathrm{v}}$ and -SPA Aptian-earliest Albian angiosperm leaves we measured, including some of the austrobaileyoids and chloranthoids, came to be deposited in coarsegrained, low-carbon sediments interpreted as sampling the front of regenerating vegetation on riparian point bars (Doyle and Hickey 1976; Hickey and Doyle 1977; Taylor and Hickey 1996). By contrast, no extant Austrobaileyales and Chloranthales occur in the pioneer thickets of open sandy point bars in lowland tropical and temperate riparian vegetation (Feild 2009; Feild et al. 2009). This extant exclusion has a physiological basis, because living terrestrial basal angiosperms cannot tolerate the high evaporative demand and wide fluctuations in water availability found in riparian point bar zones (Puhakka et al. 1992; Rood et al. 2003; Merigliano 2005; Robertson and Augspurger 1999). When extant basal angiosperm taxa with low- $D_{\mathrm{v}}$ leaves are forced into high evaporative demand, chronic photoinhibition of leaf photosynthesis, dysfunction of flowering, shoot dieback, and/or whole plant mortality occur even when soils are prevented from drying down (Feild et al. 2009).

In view of fossil ecomorphic traits linked to low drought tolerance (see above), austrobaileyoid and chloranthoids also would be expected to be excluded from sunny riparian point bars. Thus, low water stress tolerance in these early angiosperms rejects one hypothe- sis for why extant basal angiosperms do not equal early angiosperms. Unlike Ginkgo, which was likely displaced from riparian zones by angiosperms (Royer et al. 2003), the living descendants of low $D_{\mathrm{v}}$ chloranthoids and austrobaileyoids-Chloranthales and Austrobaileyales-cannot represent the sun ruderals of the Cretaceous that lost out and secondarily retreated to the forest understory following competitive displacement by later waves of more metabolically escalated angiosperms in the ancestral sunny, disturbed riparian zone.

The highly sensitive turgor relations (i.e., wilting at a loss of $<8 \%$ relative water content and leaf water potentials from -0.8 to $-1.2 \mathrm{MPa}$ ) of extant basal angiosperm leaves, and by inference those of austrobaileyoids and chloranthoids, means that even the highest $\mathrm{CO}_{2}$ concentrations predicted for the Cretaceous $\left(\sim 2000 \mu \mathrm{L} \mathrm{L}^{-1}\right)$ will not save enough water to empower such plants into sites with high evaporative load (Jones 1993; Sperry 2003; Sperry et al. 2007; Feild et al. 2009; Royer 2010). More broadly, there is no evidence that elevated $\mathrm{CO}_{2}$ can shift the canopy positioning or evaporative niche of any extant species. Studies reporting the effects of increased $\mathrm{CO}_{2}$ on leaf gas exchange and water relations demonstrated small or no change in water use, leaf water potential under maximum evaporative load, leaf and stem xylem hydraulic conductance, and drought tolerance under high $\mathrm{CO}_{2}$ (Kerstiens 1998; Wullschleger et al. 2002; Körner 2009). It is notable that trait values were invariant from the Aptian-earliest Albian to early Paleocene (a 40-Myr-long period) despite considerable atmospheric and ecological change through this interval (Wing and Boucher 1998; Lupia et al. 1999; Royer 2010). However, future fossil tests are needed to test whether water use physiologies of extinct austrobaileyoids or chloranthoids changed in ways different from living relatives during from the Paleocene to Quaternary. We suggest that the indirect effects of $\mathrm{CO}_{2}$ on varying regional evaporative demand by increased global temperature, feedbacks with cloudiness, and variations in the intensity of the global hydrological cycle were more impor- 
tant in influencing ecological distribution of Early Cretaceous angiosperms (White et al. 2001; Ufnar et al. 2008).

Instead, the depositional patterns of Aptian-early Albian angiosperms investigated are probably explained by taphonomic complexities. Hickey and Doyle (1977) suggested that the small size, fragmentary nature, and rarity of Zone I leaves were consistent with short-distance transport. Such small transport possibilities from understory sites are highly plausible because the depositional environments responsible for leaf compression fossil assemblages formed by meandering riparian zones and floodplains are complex in ways that obscure the specification of evaporative preference based on sediments alone (Gastaldo et al. 1987; Robertson and Augspurger 1999; Feild et al. 2004; Merigliano 2005; Richardi-Branco et al. 2009). Importantly, the regeneration niches of Austrobaileyales and Chloranthales provide living proof that microsites combining fluvial disturbance with low evaporative demand, low carbon, and sandy sedimentology exist (Feild et al. 2004; Ito et al. 2006; Feild 2009). Such dark and disturbed sites are often near higher flowenergy channels in tropical floodplain zones, semi-shaded stream margins (not necessarily with tall closed forest canopies) along upstream cutbanks of floodplains (Ito et al. 2006; Feild and Arens 2007; Feild et al. 2009).

Veins Versus Stomata and the Retrodicting Fossil Leaf Gas Exchange Capacity from Leaf Structure.-Our data allowed us to test the accuracy of different models for reconstructing the gas exchange performance of fossil leaves. Diffusional maxima calculated from stomatal pore anatomy were much less accurate than analyses based on vein density to predict the maximum capacity of leaves to lose water and take up $\mathrm{CO}_{2}$ (Fig. 5). These results emphasize the advantages of measuring veins over stomata to infer gas exchange capacity of fossil leaves.

Why are stomata-based estimates of maximal stomatal conductance less accurate than those derived from veins? A key problem is that stomata function through movement. Animate functioning means that experimentally difficult-to-test assumptions must invari- ably be made about what length-to-width ratios $\left(P_{\mathrm{L}}: P_{\mathrm{W}}\right)$ of the pore define the maximal diffusive potential (Van Gardingen et al. 1989; Kaiser 2009). The standard approach has been to assume that maximal width is a constant fraction of the pore length (Osborne et al. 2004; Franks and Beerling 2009). However, $P_{\mathrm{L}}: P_{\mathrm{W}}$ has a phylogenetic component across vascular plants (Franks and Farquhar 2007). Such an approach is inaccurate for clades such as grasses that open maximally at a oneto-one ratio of $P_{\mathrm{L}}: P_{\mathrm{W}}$ (Franks and Farquhar 2007). Nymphaeales may represent a similar case. If $P_{\mathrm{L}}: P_{\mathrm{W}}$ is an assumed one-to-one ratio for Nymphaeales' stomata, then calculated stomatal conductance maxima for most species fall on the one-to-one line with measured stomatal conductance. Unknown maximal pore dimensions are important because small errors in pore area have large effects on calculated conductances for one-dimensional diffusion (Parlange and Waggoner 1970). Such errors are most problematic when the stomatal area is large, resulting from largesized stomata or high stomatal density (Fig. 6A). Another significant unknown is the effects of stomatal ornamentations, such as crypts, plugs, and peristomatal rims, which pare back effective pore area (Brodribb and Hill 1997). For stomatal vestibules of Austrobaileyales and Chloranthales, at least, the effects on calculated conductance are small.

By contrast, veins are fixed in space by mesophyll tissue, which means that hydraulic distribution is approximated by a static geometry. Geometric spacing of veins is often well preserved in fossils because veins are lignified. Veins, however, are not without significant problems. Nymphaeales, for example, illustrate that aquatic plants represent a functional type with venation-dependent, liquid-phase transport uncoupled to the capacity for diffusive gas exchange. Future studies could elucidate how vein construction costs and how major versus minor vein hydraulics influence leaf gas exchange capacity (McKown et al. 2010).

\section{Conclusions}

The low vein densities and low maximal stomatal pore areas found in late Aptian- 
early Albian fossil terrestrial angiosperm leaves indicate that high leaf gas exchange capacities evolved later than previously assumed during angiosperm evolution (Feild et al. 2004; Brodribb and Feild 2010). Although previously at least one taxon from Zone I sediments was proposed as adapted to the forest understory (Doyle and Hickey 1976), our results expose a diversity of early angiosperms that functioned with low gas exchange capacities and low drought tolerance. During the Aptian-earliest Albian, angiosperms were minor ecological players, making up less than $5 \%$ of the global abundance and species diversity (Lupia et al. 1999; Heimhofer et al. 2005; McElwain et al. 2005). Consistent with this pattern, angiosperm leaves from the Zone I of the Potomac Group explored only $10 \%$ of the functional morphospace of leaf vein densities exhibited by modern angiosperms (Boyce et al. 2009; Brodribb and Feild 2010). Thus, many of the Zone I taxa of the Potomac Group fossil leaves that originally motivated the ancestral weed hypothesis did not function with high gas exchange capacities and opportunistic energy use as found in modern weedy angiosperms. The vast majority of living terrestrial basal angiosperms were similarly limited in their exploration of this functional performance space.

Although to our knowledge the fossil leaves measured represent the oldest assessed for ecophysiological performance so far, our work is limited in two important ways: the fossils sampled represent a single region in space and time, and they are not the earliest known angiosperms. Therefore, other gas exchange capacities could be ancestral. Fossil leaves from other localities that are coeval with Zone I of the Potomac Group or 5-10 Myr older are known (Sun and Dilcher 2002; Cuneo and Gandolfo 2005; Coiffard et al. 2007; Archangelsky et al. 2009). In addition, an older radiation of the angiosperm clade, nearly 20 Myr older than Zone I of the Potomac Group, is evidenced by fossil pollen (Brenner 1996; Doyle 1999). Nevertheless, the available structural observations for other Aptian and older fossils are consistent with the hypothesis that low leaf gas exchange capacities and drought intolerance are ancestral. All of the coeval and older leaves with preserved venation appear to be of low leaf rank, and some fossils possess chloranthoid leaf teeth-traits associated with low $D_{\mathrm{v}}$ and wet habitats (Sun and Dilcher 2002; Cuneo and Gandolfo 2005; Archangelsky et al. 2009). For the older pollen fossils, it is significant that chloranthoids represent a major component (Brenner 1996; Doyle 1999). Analogizing these fossils to extant Chloranthales and younger chloranthoid leaf fossils suggests that the plants that produced these grains functioned with low gas exchange and drought intolerance.

Finally, our results on Early Cretaceous angiosperm leaf form and function provide a first test of the extent to which extant basal angiosperms are ecophysiologically equivalent to some early angiosperms. We found that fossil leaves hypothesized as stem-lineage relatives to extant basal angiosperms possessed gas exchange capacities, and likely leaf water relations, similar to those of their closest extant descendants. Leaf carbon-water use represents a fundamental determinant of plant distribution in space and time as well as of whole plant life history (Stebbins 1974; Bond 1989; Sack and Holbrook 2006). Thus, our results provide evidence for the often inherently assumed hypothesis that comparative research on extant basal angiosperm biology reveals genuine functional signals from the Early Cretaceous (Williams 2008; Endress and Doyle 2009; Feild et al. 2009).

\section{Acknowledgments}

This research benefited from comments provided by J. Doyle, A. Iglesias, G. Jordan, C. Jaramillo, J. Williams, B. Gomez, P. Wilf, D. Royer, C. Feild, H. Feild, and K. Boyce. For helpful discussion on Dakota Formation angiosperms, we thank D. Dilcher, H. Wang, and S. Manchester (Florida Museum of Natural History). We extend our thanks to those involved in the field component of the research. In Papua New Guinea, L. Balun, R. Banka, B. Bau, K. Tuck, S. Saulei, and R. Kipranis are thanked for support. In Vietnam, we thank Ton That Minh for help in organizing fieldwork in Lam Dong Province at 
BiDoup Nui-Ba National Park. In Thailand, we thank Queen Sirikit Botanical Gardens in Chiang Mai for logistical support and field advice. For work in Peru, we thank R. Valega, J. Janovec, and M. N. Raurau Quisiyupanqui. We thank J.-Y. Meyer for help in coordinating fieldwork in French Polynesia. Field sampling was collected under permission granted by The National Institute of Natural Resources (Peru), Province Nord (New Caledonia), National Environment and Planning Agency (Jamaica), Délégation à la recherche-Polynésie française (French Polynesia), and National Research Insitute (Papua New Guinea). This research was supported by a National Science Foundation grant (IOB-0714156) to T.S.F.

\section{Literature Cited}

Ackerly, D. D., and M. J. Donoghue. 1998. Leaf size, sapling allometry and Corner's rules: a phylogenetic study of correlated evolution in maples (Acer). American Naturalist 152:767791.

Archangelsky, S., V. Barreda, M. G. Passalia, M. A. Gandolfo, M. Pramparo, E. Romero, R. Cuneo, A. Zamuner, A. Iglesias, M. Llorens, G. G. Puebla, M. Quattrocchio, and W. Volkheimer. 2009. Early angiosperm diversification: evidence from southern South America. Cretaceous Research 30:1073-1082.

Barclay, R. S., J. C. McElwain, and B. B. Sageman. 2010. Volcanic $\mathrm{CO}_{2}$ pulse activates carbon sequestration during Oceanic Anoxic Event 2. Nature Geoscience 3:205-208.

Blackman, C. J., T. J. Brodribb, and G. J. Jordan. 2010. Leaf hydraulic vulnerability is related to conduit dimensions and drought resistance across a diverse range of woody angiosperms. New Phytologist 188: doi: 10.1111/j.1469-8137. 2010.03439.x

Bond, W. J. 1989. The tortoise and the hare-ecology of angiosperm dominance and gymnosperm persistence. Biological Journal of the Linnean Society 36:227-249.

Bond, W. J., and A. C. Scott. 2010. Fire and the spread of flowering plants in the Cretaceous. New Phytologist 188: doi: 10.1111/ j.1469-8137.2010.03418.x

Boyce, C. K., T. J. Brodribb, T. S. Feild, and M. A. Zwieniecki. 2009. Angiosperm leaf vein evolution was physiologically and environmentally transformative. Proceedings of the Royal Society of London B 276:1771-1776.

Brenner, G. J. 1996. Evidence for the earliest stage of angiosperm pollen evolution: a paleoequatorial section from Israel. Pp. 91115 in D. W. Taylor and L. J. Hickey, eds. Flowering plant origin, evolution, and phylogeny. Chapman and Hall, New York.

Brodribb, T., and T. S. Feild. 2000. Stem hydraulic supply is linked to leaf photosynthetic capacity: evidence from New Caledonian and Tasmanian rainforests. Plant, Cell and Environment 23:1381-1388.

2008. The evolutionary significance of flat-leaves in the conifer, Pinus krempfii in Vietnamese rainforest. New Phytologist 178:201-209.

2010. Leaf hydraulic evolution led to a surge in leaf photosynthetic capacity during early angiosperm diversification. Ecology Letters 13:175-183.

Brodribb, T. J., and R. S. Hill. 1997. Imbricacy and stomatal wax plugs reduce maximum leaf conductance in Southern Hemisphere conifers. Australian Journal of Botany 45:657-668.
Brodribb, T. J., T. S. Feild, and G. J. Jordan. 2007. Leaf maximum photosynthetic rate and venation are linked by hydraulics. Plant Physiology 144:1890-1898.

Carpenter, K. J. 2005. Stomatal architecture and evolution in basal angiosperms. American Journal of Botany 92:1595-1615.

Coiffard, C., B. Gomez, and F. Thevenard. 2007. Early Cretaceous angiosperm invasion of western Europe and major environmental changes. Annals of Botany 100:545-553.

Cuneo, R., and M. A. Gandolfo. 2005. Angiosperm leaves from the Kachaike Formation, Lower Cretaceous of Patagonia, Argentina. Review of Palaeobotany and Palynology 136:29-47.

Doyle, J. A. 1999. The rise of angiosperms as seen in the African Cretaceous pollen record. Pp. 3-29 in L. Scott, A. Cadman and R. Verhoeven, eds. Palaeoecology of Africa and the surrounding islands, Vol. 26. A. A. Balkema, Rotterdam.

2007. Systematic value of leaf architecture across the angiosperms in light of molecular phylogenetic analyses. Courier Forschungsinstitut Senckenberg 258:21-37.

Doyle, J. A., and L. J. Hickey. 1976. Pollen and leaves from the mid-Cretaceous Potomac Group and their bearing on early angiosperm evolution. Pp. 139-206 in C. B. Beck, ed. Origin and early evolution of angiosperms. Columbia University Press, New York.

Endress, P. K., and J. A. Doyle. 2009. Reconstruction the ancestral angiosperm flower and its initial specializations. American Journal of Botany 96:22-66.

Feild, T. S. 2009. Regeneration ecology of early angiosperm seeds and seedlings: integrating inferences from extant basal lineages and fossils. Pp. 130-149 in M. A. Leck, V. T. Parker, R. L. Simpson, eds. Seedling ecology and evolution. Cambridge University Press.

Feild, T. S., and N. C. Arens. 2007. The ecophysiology of early angiosperms. Plant, Cell and Environment 30:291-309.

Feild, T. S., and L. Balun. 2008. Xylem hydraulic and photosynthetic function of Gnetum (Gnetales) species from Papua New Guinea. New Phytologist 177:665-675.

Feild, T. S., N. C. Arens, J. A. Doyle, T. E. Dawson, and M. J. Donoghue. 2004. Dark and disturbed: a new image of early angiosperm ecology. Paleobiology 30:82-107.

Feild, T. S., T. L. Sage, C. Czerniak, and W. J. D. Illes. 2005. Hydathodal leaf teeth of Chloranthus japonicus prevent guttation-induced flooding of the mesophyll. Plant, Cell, and Environment 28:1179-1190.

Feild, T. S., D. S. Chatelet, and T. J. Brodribb. 2009. Ancestral xerophobia: a hypothesis on the whole plant ecophysiology of early angiosperms. Geobiology 7:237-264

Fletcher, B. J., S. J. Brentnall, C. W. Anderson, R. A. Berner, and D. J. Beerling. 2008. Atmospheric carbon dioxide linked with Mesozoic and early Cenozoic climate change. Nature Geoscience $1: 43-48$.

Franks, P. J., and D. J. Beerling. 2009. Maximum leaf conductance driven by $\mathrm{CO}_{2}$ effects on stomatal size and density over geologic time.Proceedings of the National Academy of Sciences USA 106:10343-10347.

Franks, P. J., and G. D. Farquhar. 2007. The mechanical diversity of stomata and its significance in gas-exchange control. Plant Physiology 143:78-87.

Fuller, D. Q., and L. J. Hickey. 2005. Systematics and leaf architecture of the Gunneraceae. Botanical Review 71:295-353.

Gastaldo, R. A., D. P. Douglass, and S. M. McCarroll. 1987. Origin, characteristics, and provenance of plant macrodetritus in a Holocene crevasse splay, Mobile Delta, Alabama. Palaios 2:229240.

Glasspool, I. J., and A. C. Scott. 2010. Phanerozoic concentrations of atmospheric oxygen reconstructed from sedimentary charcoal. Nature Geoscience (in press).

Heimhofer, U., P. Hochuli, S. Burla, J. Dinis, and H. Weissert. 2005. Timing of Early Cretaceous angiosperm diversification 
and possible links to major paleoenvironmental change. Geology 33:141-144.

Hickey, L. J., and J. A. Doyle 1977. Early Cretaceous fossil evidence for angiosperm evolution. Botanical Review 43:3-104.

Hudson, P. J., J. Razanatsoa, and T. S. Feild. 2010. Early vessel evolution and the diversification of wood function: insights from Malagasy Canellales. American Journal of Botany 97:8093.

Ito, H., S. Ito, T. Matsui, and T. Marutani. 2006. Effect of fluvial and geomorphic disturbances on habitat segregation of tree species in a sedimentation-dominated riparian forest in warmtemperate mountainous region in southern Japan. Journal of Forest Research 11:405-417.

Jansen, R. K., Z. Cai, L. A. Raubeson, H. Daniell, C. W. dePamphilis, J. Leebens-Mack, K. F. Muller, M. GuisingerBellian, R. C. Haberle, A. K. Hansen, T. W. Chumley, S. B. Lee, R. Peery, J. R. McNeal, J. V. Kuehl, and J. L. Boore. 2007. Analysis of 81 genes from 64 plastid genomes resolves relationships in angiosperms and identifies genome-scale evolutionary patterns. Proceedings of the National Academy of Sciences USA 104:19369-19374.

Jones, H. J. 1993. Plants and microclimates. Cambridge University Press, Cambridge.

Kaiser, H. 2009. The relation between stomatal aperture and gas exchange under consideration of pore geometry and diffusional resistance in the mesophyll. Plant, Cell and Environment 32:1091-1098.

Keeling, H. C., O. L. Phillips. 2007. A calibration method for the crown illumination index for assessing forest light environments. Forest Ecology and Management 242:431-437.

Kerstiens, G. 1998. Shade-tolerance as a predictor of responses to elevated $\mathrm{CO}_{2}$ in trees. Physiologia Plantarum 102:472-480.

Körner, C. 1995. Leaf diffusive conductances in the major vegetation types of the globe. Pp. 463-490 in E.-D. Schulze and M. M. Caldwell, eds. Ecophysiology of photosynthesis. Springer, Berlin.

2009. Responses of humid tropical trees to rising $\mathrm{CO}_{2}$. Annual Review of Ecology and Systematics 40:61-79.

Lawson, T., W. James, and J. Weyers. 1998. A surrogate measure of stomatal aperture. Journal of Experimental Botany 325:13971403.

Lupia, R., S. Lidgard S., and P. R. Crane. 1999. Comparing palynological abundance and diversity: implications for biotic replacement during the Cretaceous angiosperm radiation. Paleobiology 25:305-340.

Lusk, C. H., I. Wright, and P. B. Reich. 2003. Photosynthetic differences contribute to competitive advantage of evergreen angiosperm trees over evergreen conifers in productive habitats. New Phytologist 160:329-336.

Maddison, W. P., and D. R. V. Maddison. 2008. Mesquite: a modular system for evolutionary analysis. http://mesquiteproject. org

Martin, R. E. 1995. Cyclic and secular variation in microfossil biomineralization: clues to the biogeochemical evolution of Phanerozoic oceans. Global and Planetary Change 11:1-23.

McElwain, J. C., K. J. Willis, and R. Lupia. 2005. Cretaceous $\mathrm{CO}_{2}$ decline and the radiation and diversification of angiosperms. Pp. 133-165 in J. R. Ehleringer, T. E. Cerling, and M. D. Dearing, eds. A history of atmospheric $\mathrm{CO}_{2}$ and its effect on plants, animals, and ecosystems. Springer, New York.

McKown, A. D., H. Cochard, and L. Sack. 2010. Decoding leaf hydraulics with a spatially explicit model: principles of venation architecture and implication for its evolution. American Naturalist 175:447-460.

Merigliano, M. F. 2005. Cottonwood understory zonation and its relation to flood plain stratigraphy. Wetlands 25:356-374.

Moore, M. J., C. D. Bell, P. S. Soltis, and D. E. Soltis. 2007. Using plastid genome-scale data to resolve enigmatic relationships among basal angiosperms. Proceedings of the National Academy of Sciences USA 49:19363-19368.

Osborne, C. P., D. J. Beerling, D. H. Lomax, and W. G. Chaloner. 2004. Biophysical constraints on the origin of leaves inferred from the fossil record. Proceedings of the National Academy of Sciences USA 101:10360-10362.

Parlange, J. Y., and P. E. Waggoner. 1970. Stomatal dimensions and resistance to diffusion. Plant Physiology 46:337-348.

Puhakka, M., R. Kalliola, M. Rajasilta, and J. Salo. 1992. River types, site evolution, and successional vegetation patterns in Peruvian Amazonia. Journal of Biogeography 19:651-665.

Retallack, G. J., and D. L. Dilcher. 1981. A coastal hypothesis for the dispersal and rise to dominance of flower plants. Pp. 27-77 in K. J. Niklas, ed. Paleobotany, paleoecology, and evolution. Praeger, New York.

. 1986. Cretaceous angiosperm invasion of North America. Cretaceous Research 7:227-252.

Richardi-Branco, F., F. C. Branco, R. J. F. Garcia, R. S. Faria, S. Y. Pereira, R. Portugal, L. C. Pressenda, and P. R. B. Pereira. 2009. Plant accumulations along the Itanhaem River Basin, southern coast of Sao Paulo State, Brazil. Palaios 24:416-424.

Robertson, K. M., and C. K. Augspurger. 1999. Geomorphic processes and spatial patterns of primary forest succession on the Bogue Chitto River, United States of America. Journal of Ecology 87:1052-1063.

Robinson, J. M. 1994. Speculations on carbon dioxide starvation, Late Tertiary evolution of stomatal regulation and floristic modernization. Plant, Cell and Environment 17:1-10.

Rood, S. B., J. H. Braatne, and F. M. R. Hughes. 2003. Ecophysiology of riparian cottonwoods: stream flow dependency, water relations, and restoration. Tree Physiology 23:1113-1124.

Royer, D. L. 2010. Fossils constrain ancient climate sensitivity. Proceedings of the National Academy of Sciences USA 107:517518.

Royer, D. L., L. J. Hickey, and S. Wing. 2003. Ecological conservatism in the 'living fossil' Ginkgo. Paleobiology 29:84104.

Royer, D. L., I. M. Miller, D. J. Peppe, and L. J. Hickey. 2010. Leaf economic traits from fossils support a weedy habit for early angiosperms. American Journal of Botany 97:1-8.

Saarela, J. M., H. S. Rai, J. A. Doyle, P. K. Endress, S. Mathews, A. Marchant, B. Briggs, and S. W. Graham. 2007. A new branch emerges near the root of angiosperm phylogeny. Nature 446:312-315.

Sack, L., and N. M. Holbrook. 2006. Leaf hydraulics. Annual Review of Plant Biology 57:361-381.

Schönherr, J, and M. J. Bukovac. 1972. Dependence on surface tension, wettability, and stomatal morphology. Plant Physiology 49:813-819.

Sperry, J. S. 2003. Evolution of water transport and xylem structure. International Journal of Plant Sciences 164:S115-S127.

Sperry, J. S., U. G. Hacke, T. S. Feild, Y. Sano, and E. H. Sikkema. 2007. Hydraulic consequences of vessel evolution. International Journal of Plant Sciences 168:1127-1139.

Stebbins, G. L. 1974. Flowering plants: evolution above the species level. Harvard University Press, Cambridge.

Sun, G., and D. L. Dilcher. 2002. Early angiosperms from the Lower Cretaceous of Jixi, eastern Heilongjiang, China. Review of Palaeobotany and Palynology 121:91-112.

Taylor, D. W., and L. J. Hickey. 1996. Evidence for and implications of an herbaceous origin for angiosperms. Pp. 232-266 in D. W. Taylor and L. J. Hickey, eds. Flowering plant origin, evolution, and phylogeny. Chapman and Hall, New York

Taylor, L. L., J. R. Leake, J. Quirk, K. Hardy, S. A. Banwart, and D. J. Beerling. 2009. Biological weathering and the long-term 
carbon cycle: integrating mycorrhizal evolution and function into the current paradigm. Geobiology 7:171-191.

Todzia, C. A., and R. C. Keating. 1991. Leaf architecture of the Chloranthaceae. Annals of the Missouri Botanical Garden 78:476-496.

Ufnar, D. F., G. A. Ludvigson, L. A. González, and D. R. Gröcke. 2008. Precipitation rates and atmospheric heat transport during the Cenomanian greenhouse warming in North America: Estimates from a stable isotope mass-balance model. Palaeogeography, Palaeoclimatology, Palaeoecology 266:28-38.

Upchurch, G. R. 1984a. Cuticular anatomy of angiosperm leaves from the Lower Cretaceous Potomac Group. Zone I leaves. American Journal of Botany 71:192-2002.

. 1984b. Cuticle evolution in Early Cretaceous angiosperms from the Potomac Group of Virginia and Maryland. Annals of the Missouri Botanical Garden 71:522-550.

1995. Dispersed angiosperm cuticles: their history, preparation, and application to the rise of angiosperms in Cretaceous and Paleocene coals, south western interior of North America. International Journal of Coal Geology 28:161227.

Upchurch, G. R., and D. L. Dilcher. 1990. Cenomanian angiosperm leaf megafossils, Dakota Formation, Rose Creek Locality, Jefferson County, Southeastern Nebraska. U.S. Geological Survey Bulletin 1915.

Upchurch, G. R., and J. A. Wolfe. 1987. Mid-Cretaceous to Early Tertiary vegetation and climate: evidence from fossil leaves and woods. Pp. 75-105 in E. M. Friis, W. G. Chaloner, and P. R. Crane, eds. The origins of angiosperms and their biological consequences. Cambridge University Press, Cambridge.
Van Gardingen, P. R., C. E. Jeffree, and J. Grace. 1989. Variation in stomatal aperture in leaves of Avena fatua L. observed by low temperature scanning electron microscopy. Plant, Cell, and Environment 12:887-897.

Vermeij, G. J. 1999. Inequality and the directionality of history. American Naturalist 153:243-253.

Volk, T. J. 1989. Rise of angiosperms as a factor in long-term climatic cooling. Geology 17:107-110.

Wang, H., and D. L. Dilcher. 2006. Early Cretaceous angiosperm leaves from the Dakota Formation, Braun Ranch locality, Kansas, United States of America. Palaeontographica, Abteilung B 273:101-137.

. 2009. Late Cretaceous angiosperm leaves from the Courtland Clay Pit, Minnesota. Palaeontographica, Abteilung B 281:143-177.

White, T., L. Gonzalez, G. Ludvigson, and C. Poulson. 2001. Middle Cretaceous greenhouse hydrological cycle of North America. Geology 29:363-366.

Williams, J. H. 2008. Novelties of the flowering plant pollen tube underlie diversification of a key life history stage. Proceedings of the National Academy of Sciences USA 105:11259-11263.

Wing, S. L., and L. D. Boucher. 1998. Ecological aspects of the Cretaceous flowering plant radiation. Annual Review of Earth and Planetary Sciences 26:379-421.

Wullschleger, S. D. 1993. Biochemical limitations to carbon assimilation in C3-a retrospective analysis of the A/Ci curves from 109 species. Journal of Experimental Botany 44:907-920.

Wullschleger, S. D., T. J. Tschaplinski, and R. J. Norby. 2002. Plant water relations at elevated $\mathrm{CO}_{2}$ - implications for water-limited environments. Plant, Cell and Environment 25:319-331. 